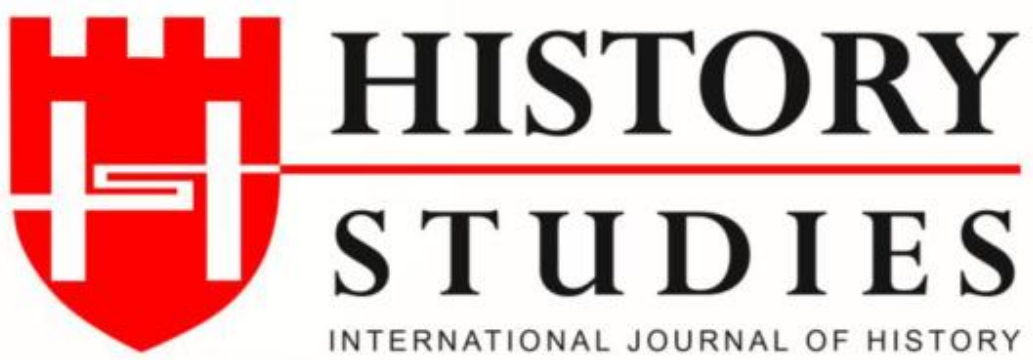

ISSN: 13094173 (Online) 1309 - 4688 (Print)

Volume 10 Issue 10, A Tribute to Prof. Dr. Yilmaz KURT, p. 145-166, December 2018 DOI Number: 10.9737/hist.2018.696

\title{
İsmail Paşa, Saray ve Babıali: Mısır İşgalinin Siyasi, İktisadî, Sosyal ve İdarî Zemininin İnşası 1863-1879
}

Ismail Pasha, Palace and Sublime Porte: Construction of the Political, Economical, Social and Administrative Base of the Occupation of Egypt 1863-1879

\author{
Dr. Musa GÜMÜŞ- Eren KORKMAZ \\ (ORCID: 0000-0002-0431-9997 / 0000-0002-2991-627X) \\ Adnan Menderes Üniversitesi - Aydın
}

\begin{abstract}
Öz: Osmanlı Devleti'nin 19. Asrının büyük bir bölümünde etkili olan Misır Meselesi, çeşitli tarihi dönüm noktalarında oluşmuş, gelişmiş ve kronik bir hâl alarak Misır'ın kaybedilmesine neden olmuştur. Bu dönüm noktalarından birisi, İsmail Paşa'nın Misır Valiliği'ne tayinidir. Bu tayin sonrası süreç, Mısır'da Osmanlı egemenliğinin günden güne daralmasına, Misır ile Osmanlı Devleti'nin bağlarının zayıflamasina ve Osmanl-Misır ilişkilerinin gerginleşmesine neden olmuștur. "Bu süreç, özellikle İsmail Pașa'nın Mısır'a Vali ardından da Hıdiv olmasından sonra daha sorunlu bir düzleme oturmuştur. Bu süreçte, Babıali ve Saray'ın Misır ile kurduğu ilişski biçimi ise bu sorunlu süreci baş edilemez hale getirmiştir. Bu iliş̧ki biçimi ve "hediyeler" karşıllğında alınan imtiyaz fermanları, hem devletin egemenlik anlaylșını eskitmis hem de devletin saygınlığına zarar vermiştir. Başta Sultan Abdülaziz, Âli ve Fuad Paşalar olmak üzere Misır ile kurulan "hediye" diplomasisi İsmail Paşa'nın kurguladiğ şsekilde yürümüş ve bu da devletin Mısır'daki hükümranlık haklarını zedelemiştir. İsmail Paşa'nın "kişisel”" gayretleriyle elde edilen ve 1866 ila 1873 yılları arasında verilen imtiyaz fermanları, İsmail Paşa'nın dönemine olduğu gibi sonraki dönemlere de sorunlu bir Misır Meselesi bırakmıştır Bu imtiyazlar ise başta Süveyş kanalı, Mısır'ın dış borç alması ve Mısır maliyesinin çöküşü gibi olaylarla Mısır'ın işgali edilmesi sürecini beslemiștir. Biz de Misır Meselesi'nin 1863-1879 dönemini ele alarak Mısır'ın işgali sürecini ortaya koymaya çalışacağız.
\end{abstract}

Anahtar Kelimeler: Mısır Meselesi, Hıdiv İsmail Paşa, Sultan Abdülaziz, Âli ve Fuad Paşalar.

Abstract: The Egypt Question, which was effective in a large section the $19^{\text {th }}$ century of the Ottoman Empire, formed, evolved and caused the loss of Egypt by becoming chronic in various historical milestones. One of these milestones is the appointment of Ismail Pasha to the Egyptian Governorship. The process after this appointment caused the Ottoman sovereignty to shrink from day to day and the weakening of the ties between Egypt and the Ottoman Empire and the tension of the Ottoman-Egypt relations. This process, got an even more problematic course, especially after the Ismail Pasha's appointment as governor and later as khedive. In this process, the relationship shape that the Bablali and Egypt made contact with the palace has made this problematic process inedible.This form of relationship and the concession edicts received in exchange for "gifts" both destroyed the state's sovereignty understanding and harmed the dignity of the state. The diplomacy of gift destablished with Egypt, especially Sultan Abdulaziz, Alli and Fuad Pashas, continued in the way that Ismail Pasha desired, and this damaged the state's sovereign rights in Egypt.The concession edicts that were gained through Ismail Pashas "personal" efforts and given between the years of 1866-1873 inherited a problematic Egyptian Question to Ismail Pasha's rule and the succeeding periods. These concessions fed the process that resulted in particular the Suez channel, Egypt's foreign borrowing and the decline of Egyptian finances and the Egypt occupation. We will try to reveal the Egyptian occupation process by taking the Egypt Problem in 1863-1879.

Keywords: Egypt Question, Khedive Ismail Pasha, Sultan Abdülaziz, Ali ve Fuad Pashas. 


\section{Giriş}

Mısır'ın, Afrika ve Asya Kıtası'nın geçiş koridoru üzerinde olması ve Akdeniz ile Kızıldeniz'i birbirine bağlaması dolayısıyla her zaman birçok devletin ilgisini çektiğini görmekteyiz. Mısır, tarih boyunca çeşitli toplumların yaşadığı coğrafya olması dolayısıyla da zengin bir tarihi geçmişe sahiptir. Eski Sami kökenli bir sözcük olan Mısır, sınır anlamına gelmektedir. ${ }^{1}$ Mısır'ın en eski yerli halkı, Kıptiler olup ve hükümdarlarına firavun denilmekteydi. Mısır, tarihi dönemler içerisinde Persler, Romalılar ve Araplar tarafından yönetilmiştir. Yavuz Sultan Selim'in 1516 Mercidabık ve 1517 Ridaniye Savaşları ile fethedilen Mısır, Osmanlı Devleti'ne bağlı salyaneli mümtaz bir eyalet şeklinde yönetilmiştir. Osmanlı Devleti, Mısır'ın fethinden itibaren Memlüklüler döneminde yürürlükte olan idarî taksimatı pek değiştirmeden devam ettirmiştir. Mısır'ın idarî taksimatı ile ilgili esaslı değişikler Mehmed Ali Paşa döneminde yaşanacaktır².

Mısır'da uzun bir dönem güçlü bir şekilde varlığını devam ettiren Osmanlı Devleti, özellikle 18. asrın ikinci yarısından itibaren buradaki etkinliğini muhafaza etmekte zorlanmaya başlamıştır. Aynı yüzyılın sonlarından itibaren Akdeniz dengesinin sömürgeci güçler açısından daha da önemli bir hale gelmesi nedeniyle mücadelelerin Akdeniz odaklı şekillenmeye başlamasına sebep olmuştur. İngiltere'nin Hindistan'daki konumu, Akdeniz'in önemini bir kat daha arttırmıştır. Akdeniz için stratejik önemi dolayısıyla Mısır, özellikle İngiltere ve Fransa'nın Akdeniz rekabetinde gündemin konularından biri haline gelecektir. Bu yüzden de Fransa başta olmak üzere büyük devletler, Mısır ile ticari ilişkilerini 18. Asır boyunca giderek sıklaştırmıştır. ${ }^{3}$

İngiltere'nin Hindistan'1 sömürgelerine katması, Akdeniz'deki dengeleri yeni bir şekle büründürmüştür. Çünkü Hindistan'ın İngilizlerin kontrolüne geçmesi başta Fransa olmak üzere büyük devletlerin, stratejilerini değiştirmesine neden olmuştur. Akdeniz planları için Mısır'1 hedef alan Napolyon Bonopart, Talleyrand aracılığıyla Direktuvar Meclisi'ni ikna ederek Akdeniz'deki planlarını gerçekleştirmek için yanına önemli komutanlarını ve bilim adamlarını alarak Mısır seferine çıkmış, 1789 Temmuzunda Mısır'ı işgal etmiştir. ${ }^{4}$ Fransa'nın Mısır'ı işgali İngiltere ve Rusya'yı endişelendirmiştir. $\mathrm{Bu}$ yüzden, sefer vuku bulduğunda bu devletlerin Osmanlı Devleti'nin yanında yer aldığı ve ortak hareket ettiği görülmektedir. Akdeniz üzerinde önemli siyasî hedefleri olan Rusya, Osmanlı Devleti nezdinde ittifak kurmak için yoğun çabalar harcamıştır. ${ }^{5}$ Rus girişimleri, Fransa'ya karşı Osmanl1-Rus İttifak

\footnotetext{
1 Durmuş Akalın-Selim Parlaz, "Nil'de İktidar Mücadelesi ve Kavalalı", Çankırı Karatekin Üniversitesi Uluslararası Avrasya Stratejileri Dergisi, C. 1, S. 1, Çankırı 2012, s.117.

2 "Medeniyet tarihi bakımindan (639-1798) yıllarında Mısır'da dört farklı devir vardır: Arap Devri, Arap-Iran Devri, İran-Türk Devri ve Türk Devri. Arap Devri; Tolun Hanedanı öncesini, Arap-Iran Devri Tolunlular, Ihşsidiler ve Fatimiler devirlerini, Iran-Türk dönemini Memlüklüler, Osmanlı idaresinde ise Mısır, Türk Eyaleti olmuştur." Carl H. Becker, "Fetihten Osmanlılar Devrine Kadar Mısır”, Milli Ë̆itim Bakanlı̆̆ İslam Ansiklopedisi, C. 8, İstanbul 1979, s. 2234; Seyyid Muhhamed es-Seyyid Mahmud, XIV. Asırda Misır Eyaleti, Marmara Üniversitesi Yayınları, İstanbul 1990, s.48.

${ }^{3}$ Alman Filozofu (Leibnitz), Mısır'ı alan Akdeniz'e hâkim olur düşüncesine sahipti. Emine Altunay Şam, Misır'ın 1882'de Ingilizler Tarafindan İsgali ve Osmanlı Devletinin Takip Ettiği Siyaset, (Ondokuz Mayı Üniversitesi Sosyal Bilimler Enstitüsü, Yayınlanmamış Doktora Tezi), Samsun 2001, s. 9-10.

${ }^{4}$ Kamil Çolak, "Mısır'ın Fransızlar Tarafından İşgali ve Tahliyesi (1798-1801)", Sakarya Üniversitesi Fen Edebiyat Dergisi, C. 10, S. 2, Sakarya 2008, s. 148-149.

${ }^{5}$ Osmanlı Devleti'ne yardım bahanesiyle Boğazlardan Rus gemilerinin geçişine karşı Sultan III. Selim, tereddüdünü şu sözlerle ifade etmiştir: "Fransız nakz-ı ahd eylemedikden sonra Rusya'lunun gemi geçirmesi muzırrdır". Fahir Armaoğlu, 19. Yüzyıl Siyasi Tarihi, TTK Yayınları, Ankara 2000, s. 84.
} 
anlaşmasının 23 Kânunuevvel 1798 tarihinde imzalanması ile sonuçlanmıştır. ${ }^{6}$ Fransa'ya karşı yapılan bu Osmanlı-Rus ittifak anlaşmasını, Osmanl1-İngiliz ve Osmanl1-Sicilya ittifak anlaşmaları izlemiştir. ${ }^{7}$ Napolyon Bonapart, bu ittifaklar karşısında aldığı askeri yenilgiler sonucunda gizlice Fransa'ya kaçmak zorunda kalmıştır. 8 Mart 1801'de Ebukır Savaşı ile ciddi bir yenilgi daha alan Mısır'daki Fransızlar, 25 Haziran 1802 tarihinde antlaşma imzalayarak Mısır'dan çekilmişlerdir. ${ }^{8}$

Mısır'da Fransız tahliyesinden sonra huzur tesis edilememiş ve Osmanlı yönetimiyle Memlûk Beyleri arasındaki çatışmalar artmıştır. Fransızlara karşı göstermiş olduğu başarılarının yanı sıra kargaşa ortamını iyi bir şekilde kullanan Mehmed Ali ${ }^{9}$, bu ortamda ulema ve halkın desteğini alarak 1805 tarihinde Mısır Valiliği'ne atanmayı başarmıştır ${ }^{10}$. Mısır'daki yerli unsurlarla hareket eden Mehmed Ali Paşa, El-Hamad'ta İngilizlerle giriştiği mücadeleyi kazanarak İngilizleri Mısır'dan çıkarmıştır. Mısır'ın müstakil hâkimi olduktan sonra da Osmanlı Devleti'nin kendisine verdiği görevleri (Vahhabiler Meselesinin çözümü, Girit İsyanı'nın bastırılması) başarıyla yerine getirmiştir. Bundan dolayı gurura kapılan Mehmed Ali Paşa, İstanbul'dan yeni isteklerde bulununca Babıâli'nin tepkisiyle karşılaştı ve ilişkilerin gerginleşmesine neden oldu. Mehmed Ali Paşa'nın Mora'daki isyanı bastırması Rusya, İngiltere ve Fransa'nın çıkarlarına dokunması dolayısıyla, bu devletler, Mora yarımadasını işgal etme konusunda anlaşarak 20 Kasım 1827 tarihinde Navarin'de demirli bulunan Osmanlı donanmasının büyük bir bölümünü batırmışlardır. ${ }^{11} \mathrm{Bu}$ olay, Sultan II. Mahmud ile Mehmed Ali Paşa'nın arasının açılmasına sebep olmuştur. Zira Mehmed Ali Paşa, ona sormadan donanmasını Mora önlerinden çekmiştir. Bundan sonra Mehmed Ali Paşa'nın Osmanlı Devleti ile ilişkilerinde gerilimli bir sürece girilmiştir. Mehmed Ali Paşa'nın Suriye seferi bu gerilimli süreci daha da keskinleştirmiş̧ir. Bu sefer, Osmanlı kuvvetlerinin Misır kuvvetleri karşısında büyük bir hezimet yaşamalarına sebep olmuş, hemen hemen bütün Suriye'yi Mehmed Ali Paşa'nın egemenliği altına sokmuş ve bu mesele, Osmanlı Devleti'nin içinden çıkamayacağı bir hal almıştır. Bu durum, II. Mahmud'a, çözüm için dişarıdan yardım ve destek almak gerektiği gerçeğini dayatmış görünmektedir. ${ }^{12}$ Büyük devletler, başlangıçta bu meselede tarafsız bir tutum sergilemişlerdi. ${ }^{13}$ Ancak Osmanlı Devleti, Mısır'daki sorun nedeniyle Rusya'dan yardım istemek zorunda kalıp Hünkâr İskelesi Anlaşması'nı imzalayınca

\footnotetext{
${ }^{6}$ İsmail Soysal, Fransız Ihtilali ve Türk-Fransız Diplomasi Münasebetleri(1789-1802), TTK Yayınları, Ankara 1987, s. 260; Hasan Şahin, “Doğu Sorunu Çerçevesinde Osmanlı-Fransız İlişkileri (Başlangıcından Paris Barışı'na 1856)", Atatürk Üniversitesi Türkiyat Araştırmaları Enstitüsü Dergisi, S. 40, Erzurum 2009, s. 291.

${ }^{7}$ Soysal, age. s. 263; Armaoğlu, age. s. 85.

${ }^{8}$ Hilal Görgün, "Fransız İşgali ve Sonrası Mısır", Türkiye Diyanet Vakfı İslam Ansiklopedisi, İSAM Yayınları, C. 29, Ankara 2004, s. 569.

9 "Muhtemel doğum tarihi (1769-1770) olan Kavalalı Mehmet Ali, Kavala'da doğmuştur. Babası İbrahim ağa'yı küçük yaşta kaybetmiştir. 1878 tarihinde Askerlik görevine başlamış, Napolyon'un Mısır'ı işgal ettiği süreçte Fransızlara karşı hazırlanan ordu içinde görev almış ve burada Fransızlara karşı göstermiş olduğu başarıdan dolayı Mısır Valisi Mehmed Hüsrev Paşa tarafindan rütbesi binbaşıllğga yükseltilerek Mısır'da ki Arnavut birliklerinin ikinci komutanı olmuştur." Muhammet Hanefi Kutluoğlu, "Kavalalı Mehmed Ali Paşa”, Türkiye Diyanet Vakfi İslam Ansiklopedisi, İSAM Yayınları, C. 25, Ankara 2002, s. 62.

${ }^{10}$ BOA, Y.EE, 34/62.

${ }^{11}$ Sevda Özkaya Özer, Osmanlı Devlet İdaresinde Mısır (1839-1882), (Firat Üniversitesi Sosyal Bilimler Enstitüsü, Yayınlanmamış Doktora Tezi), Elazığ 2007, s. 102-103; Enver Ziya Karal, Osmanlı Tarihi, C. 7, Türk Tarih Kurumu Basımevi, Ankara 2003, s. 118; Yusuf Ziya, Mısır ve Ordusu, Matbaa-i Askeriye, İstanbul 1330, s. 23-24.

${ }^{12}$ Sebahattin Samur, "Kavalalı Mehmet Ali Paşa'nın (1770-1849) Sosyal Politikaları; Mısır ve Diğer Osmanlı Eyaletlerindeki Etkisi”, Bilimname, S. 13, 2007, s. 134-135; Emine Eren, Kavalalı Mehmet Ali Paşa İsyanı Ve Mısır Meselesi, (Eskişehir Osmangazi Üniversitesi Sosyal Bilimler Enstitüsü, Yayınlanmamış Yüksek Lisans Tezi), Eskişehir 2008, s. 34; Kutluoğlu, agm, s. 83-87; Ziya, age, s. 28-29.

${ }^{13}$ Şinasi Altundağ, "İsmail Paşa” Milli Eğitim Bakanlığı İslam Ansiklopedisi, C. 5/2, Milli Eğitim Basımevi, İstanbul 1974, s. 109-117; Karal, age, s. 131.
} 
İngiltere ve Fransa telaşa düşmüşlerdir. ${ }^{14} \mathrm{Bu}$ sırada Fransızların girişimiyle, Kütahya' da taraflar toplanmış ${ }^{15}$, yapılan görüşmeler sonucunda, Suriye'nin Mehmed Ali Paşa yönetimine bırakılması, İbrahim Paşa'ya da Adana Vilayeti'nin muhassıllık olarak verilmesi şartlarını içeren bir ön anlaşma imzalanmıştır ${ }^{16}$. Bu anlaşma kimseyi memnun etmese de mesele geçici bir süreliğine rafa kaldırılmıştır. Zira kısa bir süre sonra iki ordu yeniden savaşa tutuşmuş ve Osmanlı ordusu yine hezimet yaşayarak önemli kayıplar vermiştir. 1839 yılında tahta geçen Sultan Abdülmecid Mısır Meselesi'nin aldığı vaziyetten oldukça rahatsız olmuştu ve meselenin biran önce halledilmesi konusunda istekli davranmıştır. Bu yüzden Mısır'a bir diplomatik heyet göndermiş, ancak meselenin halledilmesi konusunda bir sonuç çıkmamıştır. ${ }^{17}$ Özellikle Mısır ordularının Osmanlı orduları karşısında kazandığı başarılar sonrasında İstanbul'u tehdit etmesi dolayısıyla büyük devletler, Mısır'daki olayları uluslararası bir mesele olarak telakki etmeye başlamışlardır. İngiltere başta olmak üzere büyük devletlerin hepsinin meseleye müdahil olmaları konusunda harekete geçtiler. ${ }^{18}$ Lord Palmerston, Mehmed Ali Paşa'ya verilmiş olan Hicaz ve Suriye'nin alınmasını Fransa'ya teklif etmişse de Fransa buna olumsuz cevap vermiştir. Bunun üzerine Rusya, İngiltere, Prusya ve Avusturya elçileri Osmanlı Devleti ile anlaşarak, 15 Temmuz 1840'ta Londra Konferansı'nı toplamışlardır. ${ }^{19}$ Konferansta, Mehmed Ali Paşa'ya Mısır'ın veraseten; Akkâ'dan itibaren de Suriye'nin güneyini kayd-ı hayat şartıyla verilmesi, Kuzey Suriye, Adana ve Girit'in Osmanlı Devleti'ne iade edilmesi şeklinde kararlar alınmıştır. Ancak Mehmed Ali Paşa, bu kararları, Fransa'ya güvenerek reddetmişse de büyük devletlerin silahlı müdahalesi Mehmed Ali Paşa'nın bu kararından caymasını sağlamıştır. 1841 yılındaki anlaşma ile Mehmed Ali Paşa büyük devletlerin şartlarını kabul etmek zorunda kalmıştır. 1841 tarihli fermanla da Mehmed Ali Paşa'nın konumu Osmanlı nezdinde resmen belirlenmiş ve kabul edilmiştir. Mehmed Ali Paşa, Osmanlı Devleti'nin bir valisi olarak devlete tabiiyetini kabul etmek zorunda kalmıştır. Bundan sonra Mısır'da görece bir sükûnet devri yaşanmıştır. 1840'ların sonlarına doğru yaşının da verdiği zorluklar ve hastalıklarla mücadele etmeye başlayan Mehmed Ali Paşa, iş göremez hale gelmiştir. Eylül 1848 yılında İbrahim Paşa, Mısır valisi olarak atanmış ancak O da çok kısa güre sonra vefat etmiştir. İbrahim Paşa'dan sonra I. Abbas Paşa Mısır valisi olmuştur. Mehmed Ali Paşa da 2 Ağustos 1849 tarihinde vefat etmiştir ${ }^{20}$. İbrahim Paşa'dan sonra sırasıyla Abbas Hilmi Paşa (1848-1854) ve Said Paşa (1854-1863) Mısır'ın valileri olmuşlardır ${ }^{21}$.

\footnotetext{
${ }^{14}$ Al-Sayyid Afaf Lutfi Marsot, Mısır Tarihi Arapların Fethinden Bugüne, Çev: Gül Çağalı Güven, Tarih Vakfı Yurt Yayınları, İstanbul 2010, s. 63; Kutluoğlu, age, s. 94-95.

15 “Osmanlı Rusya ile Hünkâr İskelesi Anlaşmasını İmzalayarak Ingiltere’nin Yakındoğu'daki konumuna tehdit yöneltmiş oldu” Ömer Kürkçüoğlu, Türk-İngiliz İlişkileri (1919-1926), Ankara Üniversitesi Siyasal Bilgiler Fakültesi Yayınları, Ankara 1978, s. 20; Şam, agt, s. 27-29.

${ }^{16}$ Gideon Biger, "The First Map of Modern Egypt Mohammed Ali's Firman and the Map of 1841", Middle Eastern Studies, C. 14, 1978, s. 323; Nevzat Gündağ, "Grek-Rum ve Mehmed Ali Paşa İsyanlarının Yarattığı Müsait Ortamda Doğu Akdeniz'de Devletlerarasında Denge Arayışları", Türk Yurdu, C. 20, S. 151, Ankara 2000, s. 23.

${ }^{17}$ Rağıp Raif-Rauf Ahmed, Misır Meselesi, Matbaa-i Amire, İstanbul 1334, s. 15-16; Marsot, age, s. 76-77; Ziya, age. s. 31-32.

${ }_{18}$ Armaoğlu, age, s. 211-213.

19 Virginia H. Aksan, Kuşatılmış Bir Imparatorluk Osmanlı Harpleri 1700-1870, Çev: Gül Çağalı Güven, İş Bankası Kültür Yayınları, İstanbul 2010, s. 423-426.

${ }^{20}$ Ziya, age, s. 33.

${ }^{21}$ Suraiya Faroqhi, Osmanlı Imparatorluğu Tarihi, Çev: Ercan Ertürk, Tarih Vakfı Yurt Yayınları, İstanbul 2012, s. 92.
} 


\section{İsmail Paşa'nın Mısır Valiliğine Tayini: Mısır'da Yeni Dönemin Başlangıcı}

Osmanlı Devleti'nin Mısır ile ilişkilerinde dönüm noktası olan İsmail Paşa ${ }^{22}$, varisi Ahmet Rıfat Paşa'nın vefatı üzerine ailenin en yaşlı üyesi olması sebebiyle 18 Ocak 1863'te Mısır Valiliği' ne atanmıştır ${ }^{23}$. İsmail Paşa, yerine amcası Halim Paşa'yı naip bırakarak İstanbul'a teşekkür dileklerinde bulunmak ve fermanı resmen almak için gitmiştir. Padişah'a sadakat ve bağlığını arz eden İsmail Paşa'ya, "Birinci Osmanî Nişanı ve Sadaret Rütbesi ihsân ve tevcîhi ile bâ-Hatt-ı Hümâyûn Babıâli ye irsâl kılınarak mazmûnu münîfi ilân edilmiştir". Daha önce Mehmed Ali Paşa'ya verilmiş olan bu fermanla, söz konusu şartlarda Mısır Eyaleti ve ona bağlı yerlerin İsmail Paşa'nın idaresine verilmiştir. ${ }^{24}$

İsmail Paşa, İstanbul'a gelirken beraberinde Osmanlı devlet adamlarına verilmek üzere değerli hediyeler getirmiştir ${ }^{25}$. Padişah'a da selefi Said Paşa'nın yaptırmış olduğu buharla çalışan ve özel bir yat olan "Feyz-i Cihad' 1 " hediye ederek Mısır'a davet etmiştir ${ }^{26}$. Ayrıca İsmail Paşa, Mısır'da imtiyazlarını genişletmek düşüncesiyle Âli ve Fuat Paşalarla gizlice görüşmüştür. ${ }^{27}$ İsmail Paşa, Mısır'a geri dönmeden önce, istirahati için ayrılan Bebek'teki Kâin Misafirhanesi'nde yabancı ülkelerin elçileriyle görüşmüştür. Ramazan iftarı için Mabeyn-i Hümayun'a davet edilen İsmail Paşa, Vükela'ya kapı yoldașı hediyelerini dağıtıp iyi intibalar bırakarak Mısır'a dönmüştür. ${ }^{28}$ İsmail Paşa, Mısır'a döndükten sonra vali olarak yaptığı ilk konuşmasında; mülkî, idarî ve malî işlerde 1slahat yapacağını, ziraatın gelişmesi için çalışacağını ve angarya usulünün tamamen kaldıracağını söylemiştir. ${ }^{29}$

İsmail Paşa, vali olduktan sonra Sultan Abdülaziz'in güvenini kazanmak için saray ve Babıâli ile ilişkilerini iyi tutmuştur. Bu ilişkilerini sağlam bir zemine oturtmak için büyük meblağlarda para harcamaktan da kaçınmamıştır. ${ }^{30} \mathrm{Bu}$ durum, bir anlamda hediye diplomasisi olarak da ifade edilebilir.

Mısır'1 Avrupalı ülkeler gibi modernleştirmek düşüncesiyle hareket eden İsmail Paşa, bir çaba içerisine girmiştir. İlk iş olarak 1866 yllında Şura-yı Nüvvab isimli bir danışma

\footnotetext{
22 “İsmail Paşa, İbrahim Paşa'nın ortanca oğludur. 1830 yılında Kahire'de doğmuştur. 14 yaşına kadar Mısır'da kaldıktan sonra göz rahatsızlı̆̆ını tedavi ettirmek için Viyana'ya gönderilmiştir. Burada iki yıl kaldıktan sonra Paris'e gitmiş, burada modern ilimler ile mühendislik tahsilini yaptıktan sonra Mısır'a dönmüştür. "Altındağ, agm, s. $1115-1116$.

${ }^{23}$ Pinar, age, s. 17.

${ }^{24}$ Özer, agt, s. 155.

25 “İsmail Paşa, 1866’da Babıâli ziyaretinde bulunduğu sırada kapsamlı bir rüşvet dağıtmıştır. Padişaha Mısır vergisinin iki katına çıkartılması sözünü vermiştir” Jakab Van Klaveren, "Mısır'da Rüşvetin Gelişimi: Muhammed Ali Paşa'dan Hidiv İsmail'e Kadar", Çev: Ahmet Asker, Osmanlı Tarihi Araştırma ve Uygulama Merkezi Dergisi, S. 28, Ankara 2010, s. 233.

26 "İsmail Paşa saray ve hükümet adamlarının vasıf ve ahlaklarını çok iyi biliyordu. Kardeşi Fazıl Paşa'ya gönderdiği mektupta bu durumu şöyle ifade etmektedir: Ben padişah ile hükümetine karşı vazifelerimi bilirim; fakat benim Misır valisi olarak, ihlal edilmelerine müsaade edemeyeceğim haklarımda bulunuyor.” İbrahim Muhammed is-Sanafiri, Osmanlı Mısır Illişkileri (1863-1882), (İstanbul Üniversitesi Sosyal Bilimler Enstitüsü, Yayınlanmamış Doktora Tezi), İstanbul 1993, s. 29.

${ }^{27}$ Özer, agt, s. 156-157.

${ }^{28}$ İs-Sanafiri, s. 25.

${ }^{29}$ Özer, agt, s. 157.

${ }^{30}$ Musa Gümüş, Güç ve Diplomasi-Misır Meselesi ve Sultan II. Abdülhamid, Kitabevi Yayınları, İstanbul 2018, s. 13-15; “İsmail Paşa'nın Babıâli'ye rüşvetleri devletin otoritesini o kadar etkilemiştir ki, hatta bazllarına göre, Mısır parası Tanzimatı çürüten başlıca amillerden sayılmış ve Tanzimat sonrası devirlerde rüsvetin örneği olmuştur." İs-Sanafiri, agt, s. 29; "İsmail Paşa münasebetinde girgin, insan avlamakta pişkin, son derece kurnaz, dolap çevirmekten yorulmaz, emsali pek az bulunan bir idarecidir. "İsmail Hami Danişmend, İzahlı Osmanlı Tarihi Kronolojisi, C. 4, Türkiye Yayınevi, İstanbul 1972, s. 207.
} 
meclisini, 1875 yılında da yabancıların Mısır'da kolayca ticari faaliyet sağlaması için Karma Mahkemeleri kurmuştur. Misır ve dünya kamuoyunda en çok tartışılan Köle Ticaretini yasaklamaya dönük çalışmalarında başarılı bir sonuç almıştır. İsmail Paşa'nın bu başarısı, Avrupa kamuoyunda saygınlığını artırmıştır. ${ }^{31}$

\section{Sultan Abdülaziz ve İsmail Paşa}

İsmail Paşa, Osmanlı Devleti ile ilişkilerini kurgularken saray ve Babıâli’nin teveccühüne önem vermiştir. $\mathrm{Bu}$, aslında Mısır'ın Osmanlı Devleti'yle olan bağına ciddi zararlar verecek bir tarzda gerçekleşmiştir. Bunun, İsmail Paşa'ya yansıması ise müstakil bir hükümdar gibi davranacak hukukî zemini oluşturmak şeklinde olmuştur. İsmail Paşa'nın bu yaklaşımı, aslında 1841 tarihli fermanla, Mısır Valiliği'nin veraset yoluyla Mehmed Ali Paşa'nın ailesinin uhdesine verilmesinin doğurduğu hukukî gerekçelere dayanmaktadır. İsmail Paşa, bu sistemi Osmanlı Devleti'nden daha bağımsız hareket edebilecek bir hale getirmeyi amaç edinmişti. İşte İsmail Paşa'nın saray ve Babıâli ile kurduğu ilişki biçimi Mısır'ın mukadderatını etkileyen önemli gelişmelerin yaşanmasına sebep olmuştur.

İsmail Paşa, Osmanlı Devleti'nden, ileride gerçekleşecek taleplere zemin hazırlamak için uygulamaya koyduğu "hediye diplomasisi"ne ilk olarak Said Paşa'nın yaptırmış olduğu şatafatlı bir vapurun Sultan Abdülaziz'e hediye etmesi ile başlamıştı. İsmail Paşa, Sultan Abdülaziz'i Mısır'a davet ederek ve onu Mısır'da "çok iyi” ağırlamaya ve Sultan Abdülaziz'in nezdinde makbul bir "kul" olduğunu göstermeye imkân bulmak için Sultan Abdülaziz'i Mısır'a davet etmişsirir ${ }^{32}$. Sultan Abdülaziz'i Mısır'a gitmesinde İsmail Paşa'nın eniştesi olan Sadrazam Yusuf Kamil Paşa ile Âli ve Fuad Paşaların teşviklerinin etkili olmuştur. İstanbul açısından bu ziyaretin, Mısır'ın Osmanlı Devleti'nin bir toprağı olduğu ve bağların, böylece yeniden sağlam bir şekilde kurulması gerektiği mesajını vermek gibi bir amaçları bulunmaktaydı. Bu ziyaret, Avrupalı devletlerin de dikkatini çekmiş ve bu devletler tarafından farklı şekillerde yorumlanmıştır. Fransa, Sultan Abdülaziz'in Mısır ziyaretini, Osmanlı Devleti'nin mali sıkıntılardan kurtulmak için İsmail Paşa'dan yardım istemesi olarak görmüş ve Mısır'daki genel konsolosu Tasto'dan padişahın Mısır'daki faaliyetlerini gözlemlemek ve Süveyş Kanalı ile ilgili kararlarını öğrenmek için firsat olarak görmüştür. İngiltere ise bu ziyareti Süveyş Kanalı açısından değerlendirmiş, Ferdinand Lesseps'in kanal projesi tasdikinden endişelenmiş ve İstanbul'daki İngiliz sefirinden bu ziyareti engellemeye çalışmıştır. ${ }^{33}$ Sultan Abdülaziz ise bunları dikkate almayarak 4 Nisan 1863 tarihinde, yerine Sadrazam Yusuf Kamil Paşa'yı kaymakam olarak bıraktıktan sonra yanına veliaht Murat, Şehzadeler Yusuf İzzeddin, Abdülhamit ve Reşat'1 ve devlet erkânından Serasker Fuat Paşa ile Kaptan-1 Derya Ateş Mehmet Paşa ile hocası Akşehirli Hasan Fehmi Efendi'yi alarak Feyz-i Cihâd vapuru ile Mısır ziyaretine çıkmıştır ${ }^{34}$. Sultan Abdülaziz ve beraberinde gelen kişileri

\footnotetext{
${ }^{31}$ Süleyman Kızıltoprak, Mısır'ın İngiltere Tarafindan İşgali Osmanlı'nın Diplomasi Savaşı (1882-1887), Tarih Vakfi Yurt Yayınları, İstanbul 2010, s. 29.

32 Mehmed Arif, Başımıza Gelenler, İrfan Yayınevi, İstanbul 1976, s. 601; Nejdet Gök, "Mütercim Halimi Efendi'nin Notları Çevresinde Sultan Abdülaziz'in Avrupa Seyahati ve Sonuçları(21 Haziran 1867- 7 Ağustos 1867)", Tarihin Peşinde Uluslararası Tarih ve Sosyal Araştırmalar Dergisi, S. 7, 2012, s. 170.

${ }^{33}$ İs-Sanafiri, agt, s. 30-31.

${ }^{34}$ Ahmed Bedevi Kuran, Osmanlı Imparatorluğunda İnkılâp Hareketleri ve Milli Mücadele, Türkiye İş Bankası Kültür Yayınları, İstanbul 2012, s. 66-67; İs-Sanafiri, agt, s. 32; "Sultan Abdülaziz, Kavalalı Mehmed Ali Paşa isyanindan beri adeta ayrı bir devlet halini almaya başlayan bu Osmanlı vilayetine gitmekle Misırlıların Osmanlı Devleti'ne bağlılıklarını kuvvetlendirmeyi amaçllyordu. Mısır Valisi İsmail Paşa, tertiplediği muhteşem eğlence âlemleriyle padişahın gözüne girmeyi başardı. Daha sonraki tarihlerde Mısır'ın Osmanlı Devleti'nden ayrılmasını kolaylaştıracak imtiyazları koparmak için uygun ortamı sağlamış oldu. Diğer taraftan, Abdülaziz'in sefahat ve israfa düşmesinde Misır'daki bu eğlence âlemlerinin de büyük rolü olduğu ileri sürülmektedir" Cevdet Küçük, “Abdülaziz", Türkiye Diyanet Vakfi İslam Ansiklopedisi, C. 1, İSAM Yayınları, İstanbul 2013, s. 180.
} 
İskenderiye Limanı'nda karşılayan İsmail Paşa, hürmet göstergesi olarak sayısız top atışında bulunmuştur. İskenderiye'de Misır Hükümeti’nin ileri gelenleri ve konsoloslar padişah tarafından kabul edilmiştir. ${ }^{35}$ Daha sonra Kahire'ye doğru yola çıkmıştır. Burada bulunduğu sırada babasının rakibi olan Mehmed Ali Paşa Türbesi'ni ziyaret etmiştir. Sultan Abdülaziz Mısır'da on gün kaldıktan sonra İstanbul'a geri dönmek üzere yola çıkmıştır. ${ }^{36}$

Bu ziyaret İsmail Paşa'nın meşruiyetine dair olumsuz yaklaşımları ortadan kaldırmış ve Mısır'daki konumunu oldukça güçlendirmiştir. İsmail Paşa'nın şahsına dokunacak siyasî meselelere yer verilmemiş, bilakis Paşa ve devlet adamlarına münasip nişanlar verilmiştir. Buna ilaveten Paşa'nın annesi ile üç karısına yaklaşık üç milyon Frenk değerinde mücevherat alınmış ve İsmail Paşa'nın dört oğluna da feriklik rütbesi verilmiştir. ${ }^{37} \mathrm{Bu}$ jestlere karşılık vermekten geri durmayan İsmail Paşa da hem Sultan Abdülaziz'e hem de devlet adamlarına bir yüklüce hediye takdim etmiş, böylece Mısır'daki ilişkiler hediye diplomasisine dönmeye başlamıştır. Bununla yetinmeyerek Fuat Paşa'ya ileride hizmetlerinden yararlanma düşüncesiyle altmış bin lira daha vermiştir. İsmail Paşa, Paris’te sipariş ettiği on iki bin adet tüfeği fabrikasından aldırarak İstanbul'da bulunan Sultan Abdülaziz'e hediye olarak göndermiştir. ${ }^{38}$

İsmail Paşa bu faaliyetlerini, "bir taraftan ubûdiyet-i mahsusa iddi'âstyla cennet-mekân Sultan Abdülaziz Han hazretlerini iğfâl ve bir taraftan Mısır'da hilâfet-i 'uzmânın nüfûz ve iktidârına imhâya ibtidâr ile saltanat- seniyye 'aleyhinde ifsâda kadar tebsi'-i dâ 'ire-i efkâr etmek,"39 şeklinde yürütmüştür. İsmail Paşa'nın Sultan Abdülaziz'in Mısır'a gelmesini Mısır'daki meşruiyetini arttırmaya yönelik olarak kullandığı şüphesizdir. ${ }^{40}$ İsmail Paşa akıllı bir siyaset yürüterek Sultan Abdülaziz'in Mısır'da bulunduğu sırada tabiiyet vergisini yaklaşık iki katına çıkarmış, böylelikle de Sultan Abdülaziz'in gözünde önemli bir mevkie yükselmiştir. $\mathrm{Bu}$ uygulama, İsmail Paşa tarafından ilerleyen yıllarda sonuna kadar kullanılacaktır. ${ }^{41}$

Netice itibariyle Sultan Abdülaziz'in ${ }^{42}$ Mısır seyahati ile angarya usulü kaldırılmış, Süveyş Kanalı'nın tarafsızlığı sağlanmış ve Mısır halkının Hilafet makamına bağlılığı kuvvetlenmiştir. İngiliz ve Fransızların İsmail Paşa'yı Babıâli'ye karşı kışkırtmaları da sonuçsuz kalmıştır. ${ }^{43}$

İsmail Paşa'nın peşine düştüğü en önemli husus, Mısır'da müstakil bir şekilde hareket edecek hukukî zemin oluşturmaktır. Yürüttüğ̈̈ hediye diplomasisi ile elde ettiği fermanlar Mısır'ın mukadderatını etkileyen süreci beslemiştir. İsmail Paşa, İstanbul'a beş kez gelmiş ve her gelişini bir imtiyaz fermanı ile süslemiştir. Bu fermanlar, 1866 Fermanı, 1867 Fermanı, 1870 Fermanı, 1872 Fermanı ve 1873 Fermanı'dır. ${ }^{44}$

\footnotetext{
35 'Sultan Abdülaziz 1866'de Misir' ziyaret eder. Yavuz Sultan Selim'in 1517'de fethinden beri imparatorluğun bu köşesine ziyarete giden ilk Osmanlı padişahıdır. Görülmemişs bir debdebeyle karşılanan Abdülaziz bu ihtişamdan pek memnun kalır." Emine Fuat Tugay, Bir Aile Ü̧̧ Asır, Çev: Şeniz Türkömer, Türkiye İş Bankası Kültür Yayınları, İstanbul 2015, s. 223.

${ }^{36}$ Ali Kemal Aksüt, Sultan Azizin Misır ve Avrupa Seyahati, Ahmet Sait Oğlu Kitabevi, İstanbul 1944, s. 25.

${ }^{37}$ Aksüt, age, s. 68.

38 İs-Sanafiri, agt, s. 33-34.

${ }^{39}$ Y.PRK.MK. 1/94; Gümüş, age, s. 13.

${ }^{40}$ William Morton Pullerton, The Memoirs Of İsmail Kemal Bey, Constable And Company Ltd, London 1920, s. 94.

${ }^{41}$ Edward Dicey, The Egypt of The Future, William Heinemann, London 1907, s. 65; Sir Alfred Milner, England in Egypt, Edward Arnold Press, London 1902, s. 36.

${ }_{42}$ "Bazı rivayetlere göre bu seyahatte yaşanmış olan sefahat ve eğlenceler, Sultan Abdülaziz'in ahlakını bozmuş ve bu durum ileride sefahat ve israfa doğru eğilim göstermesine neden olmuştur”. Danişmend, age, s. 204.

${ }^{43}$ İs-Sanafiri, agt, s. 34.

${ }^{44}$ Akalın-Parlaz, agt,s. 91; Gümüş, age, s. 13.
} 


\section{İsmail Paşa'nın "Bağımsızlık" Fermanları}

İsmail Paşa, Sultan Abdülaziz ve Bâbıâli nezdinde gerçekleştirdiği görüşmede, 1840-41 fermanının tadilinin uygun olduğunu ve Fâzıl Paşa'nın Mısır Valiliği’ne gelmesinin çok zararlı olacağını söyleyerek veraset sisteminin değiştirilmesini talep etmiştir. İsmail Paşa'nın bu talebi, Fuad ve Âli Paşalar tarafından da uygun bulunmuş ve 12 Muharrem 1283/ 27 Mayıs 1866 tarihinde Mısır Veraset Fermanı çıkarılmıştı ${ }^{45}$. Bu fermanla, Mısır'da veraset sistemi değiştirilmiş, en büyük evladın tahta çıkması kaidesi koyulmuş, Mısır vergisi 80.000 keseden 150.000 keseye çıkarılmış ve Mısır ordusunun 30.000'e kadar arttırılabilmesine izin verilmiştir. "Tarihe Veraset Fermanı olarak geçen bu belge sayesinde Misır, Osmanl Devleti'nden yarı bağımsız bir hal kazanmıştır". ${ }^{47}$ Ahmet Lütfi Efendi, fermanın ilanını, "sene-i Mezkûre (1283/1866) 'nin havâdis-i mühimme ve vakâyi'-i acibesi”" olarak nitelemiştir. İsmail Paşa'nın bir sonraki hedefi ise, "kendisinin sair valilerden mümtaz olmak ve veraset sistemine muvafik bulunma"sını sağlamaktı. ${ }^{48}$ İsmail Paşa bu fermanla birlikte veraset sistemini kendi istediği şekle soktuktan sonra hediye diplomasisine devam ederek yeni fermanların peşine düşmüş, bunun için yeniden İstanbul yolunu tutmuştur. İsmail Paşa'nın yeni planı, Mısır'da tasarladığı yeni istikbal için, iç işlerinde ve malî ve idarî işlerde, yeni düzenlemeler yapabilecek hareket alanı oluşturmaktı. İsmail Paşa, gerçekleştirdiği hediye diplomasisi ile 5 Safer 1284/8 Haziran 1867 tarihinde yeni fermanı almayı başardı ${ }^{49}$. Bu fermanla İsmail Paşa, "Hıdiv" Osmanlı eyaletlerinde tatbik edilmekte olan Gülhane Hatt-1 Hümayunu'nda yer alan hükümlere ilâve olarak, içişleri ile ilgili düzenlemeler yapma müsaadesi almıştır. Yine yabancı ülkelerle gümrük ve yabancilarla zabıta, transit ve postaya dair düzenlemeler akdetme salâhiyetlerini de elde etmiştir. ${ }^{52}$ Bunlar için Babiâli’yi haberdar etmesi yeterli sayılmıştır. ${ }^{53}$ Mısır, bu şekilde özerkliğe kavuşmuştur ${ }^{\zeta 4}$. İsmail Paşa, tasavvurlarını gerçekleştirmek için

\footnotetext{
45 “Ferman'ın ana hükümleri: 1- Mehmet Ali Paşa'ya verilmiş olan Mısır valiliği veraset sisteminin ta'dili ile bundan böyle ekberiyet kaidesi yerine Valilik doğrudan doğruya valiliğin erkek evlatlarının büyügüne münhasır tutulacak. 2- Mısır valiliğinin mülhakatından olan Sevakin ve Müsavva Kaymakamlıkları sözü geçen fermanın hükümlerine göre ikba olunacak. 3-Misır valiliği gelirinden ylllk maliye hazinesine ödemekte olduğu seksen bin kese verginin yüz elli bin keseye çıkarllması. 4-Mısır ordusu otuz bine kadar artırılacaktır”. İs-Sanafiri, agt, s. 46; Pinar, age, s. 28.

${ }^{46}$ İs-Sanafiri, agt, s. 47; Pınar, age, s. 50-52.

${ }^{47}$ Mustafa Öztürk, “Arap Ülkelerinde Osmanlı İdaresi”, History Studies Ortadoğu Özel Saylsı/Middle East Special Issue, Samsun 2010, s. 333.

${ }^{48}$ Şam, agt, s. 50.

49 “8 Haziran 1867'de ilan edilen ferman ile Babıali-Mısır ilişkilerinde yen bir dönemin başladığını düşünmek yanlış olmayacaktır". Pınar, age, s. 39

50 "İsmail Paşa, Padişahın kendisine verdiği Hıdiv unvanı karşısında, İstanbul'a gönderdiği vergiyi 60 bin Cüneyh artırdı. Padişahın bir unvan bağışlaması senelik yeni bir gelir karşılığında çok önemli bir ayrıcalık değildi. Osmanlı Padişahına göre bu unvan Osmanl hiyerarşisinde bir şey ifade etmiyordu. Ama İsmail Paşa bu unvanla amacına bir adım yaklaştığını varsayıyordu" Kızıltoprak, age, s. 34

${ }^{51}$ Wolff, age, s. 293; Arthur Brome Weigall, A History of Events in Egypt from 1798 to 1914, Charles Scribner's Sons, New York 1915, s. 269; "Ísmail Paşa büyükbabasının gayri resmî olarak kullandı̆̆ı bir unvan olan, hükümdar anlamına gelen Farsça bir sözcükle, Hıdiv olarak tanımalarını sağlamayı başardı. Unvan, aynı derecede özerkliğe sahip olmayan diğer Osmanlı valileri ile kendi konumu arasındaki farklılĭ̆g vurgulamayı amaçliyordu" Marsot, age, s. 68; “...özellikle 1867 yılında Mısır valisi İsmail Paşa'ya "Hıdiv” unvanı verildikten sonra Misır ile Osmanlı arasındaki iliş̧kiler kritik bir döneme girmiştir. Kendini bölgenin hâkimi olarak görmeye başlayan Hıdiv İsmail Paşa, Osmanlı'dan tamamen bă̆ımsız bir yönetim kurma faaliyetlerini hızlandırmıştır” Mahmud Aybi, II. Abdülhamid'in Ortadoğu Politikası, (Muğla Üniversitesi Sosyal Bilimler Enstitüsü, Yayınlanmamış Yüksek Lisans Tezi), Muğla 2009, s. 69.

52 İs-Sanafiri, agt, s. 64.

${ }^{53}$ Şam, agt, s. 50.

${ }^{54}$ Valentine Chirol, “The EgyptianQuestion”, Journal of theBritish Institute of International Affairs, V: 1, I: 2, 1922, s. 55.
} 
hemen harekete geçerek Nubar Paşa'y1 ${ }^{55}$ özel memuriyetle Avrupa'ya göndermiştir. ${ }^{56}$ Nubar Paşa'nın en önemli gündem konusu, Karma mahkemelerin kurulması için Avrupa'dan olur almaktı. ${ }^{57}$ Nubar Paşa, bu konuda Mısır'daki ikili kontrolün (Dual Control) üyeleri olan İngilizleri ve Fransızları memnun ve ikna etmek için çalışmalara başladı. Karma mahkemeler ile ilgili düzenlemeler için kolları sıvadı. Böylelikle Mısır'da hukuk sisteminin batılı hukuk sistemine hem içerik ve hem de şekil olarak uygun hale getirilmesine çalışılmıştır. ${ }^{58}$ İsmail Paşa'nın aldığı fermanlarla edindiği hareket serbestîsi ve ortaya koyduğu faaliyetler, Mısır'ın İstanbul ile ilişkilerinin gerginleşmesine sebep olmuştur. Bu yüzden İsmail Paşa'ya verilen imtiyazların geri alınması için harekete geçilmiş, Hıdiv'in imtiyazları kaldırılmak istenmiştir. Fakat bu, fermanların, büyük devletlerin onayı ile verilmesi dolayısıyla mümkün olmayacaktır. $\mathrm{Bu}$ yüzden, büyük devletlerin tepkisini çekmeden İsmail Paşa'nın yetkileri tanımlanmak suretiyle onun Osmanlı Devleti'nin bir memuru olduğunu ifade edecek ve onun yetkilerinin sınırlarını açıklayacak bir ferman verilmesi kararlaştırılmıştır. ${ }^{59}$ İşte 27 Kasım 1869 tarihli ferman bunu sağlamak için çıkarılmıştır. ${ }^{60}$ Bu yeni ferman, İsmail Paşa'yı oldukça rahatsız etmiştir. Zira bu ferman, İsmail Paşa'nın istiklal tasavvurlarına mani bir hal ihtiva ediyordu. Yeniden hediye diplomasisini devreye sokan İsmail Paşa, yeni bir fermanın peşine düşmüştür. Alınacak yeni fermanın temel amacı, "özellikle (İstanbul'dan) müsaade olmadan istikraz edememek" şartının kaldırılmasını sağlamaktı. Sultan Abdülaziz’i ikna ederek söz almış, Mithat Paşa istemeyerek de olsa bunu kabul etmek zorunda kalmıştır. Böylelikle 7 Receb 1289/10 Eylül 1872 tarihli ferman İsmail Paşa'nın istediğine yakın bir şekilde çıkmıştır. Mithat Paşa'nın engellemeleri nedeniyle borçlanma yetkisi verilmemişti. İsmail Paşa bu yetkiyi fermana ek olarak verilen Hatt-1 Hümayun ile Mithat Paşa'dan gizli olarak elde etmiş̧tir. Bu fermanda da "hediye" diplomasisi oldukça etkili olmuştur.

İsmail Paşa'nın 1872 tarihli fermanı aldıktan sonra faaliyetlerine son verdiğini ya da "hediye" diplomasisini terk ettiğini söylemek mümkün değildir. Onun yeni hedefi, şimdiye kadar aldığı imtiyaz fermanlarını tek bir fermanda birleştirmek ve yeni imtiyazlar almak üzere yeniden İstanbul'un yolunu tutmuş, "hediye" diplomasisini yeniden devreye sokmuştur. Bu

\footnotetext{
55 "Nubar Pasha realized the most successful and controversial actions during the reign of Ismail Pasha (18631879). There have been important changes in the administrative structure of Egypt during the period of Ismail Pasha. The Minister of Foreign Affairs Nubar Pasha had important contributions implementing these changes".... "In order to achieve these goals peacefully, Ismail Pasha needed Nubar Pasha's diplomatic skills choose and the trust of the Ottoman Sultan Abdulaziz. In this context, he tried to improve his relations with Istanbul by giving some valuable presents to the notables of the Ottoman State under the title "kap tyoldaşl hediyesi (door companion presents) 'Kiziltoprak, age, s. 229-230.

${ }^{56}$ Cannon, Byron David, "A Reassessment of Judicial Reform in Egypt, 1876-1891”, The International Journal of African His-torical Studies, V: 5, I: 1, Boston 1972, s. 52-53.

57 "1876 yılından itibaren uygulanmaya bașlayan Karma Mahkemeler, Misırlılar ile Avrupalılar arasındaki anlaşmazlıkları çözmek için kullanılmıştır. Bu mahkemeler, çiftçilerin pek de lehine olmamıştır, çünkü mahkemelerde konuşulan dil yabancıdır ve yargılamalar Avrupalı hâkimler tarafindan, Avrupa hukuk anlayışına göre yapılıyordu. Tüm bu uygulamalar, yerel çiftçi için yeni ve yabancı uygulamalardl. Köylüler kendi topraklarında yabancı konumuna düşmüşlerdi. Avrupalı tefeciler, çiftçiler borçlarını zamanında ödemedikleri takdirde topraklarına el koyma hakkina sahip olmuşlard. Bu da daha önce toprak üzerindeki ömür boyu kullanma hakkına sahip olan bu çiftçilerin moral ekonomi anlayışına zarar veriyordu” Bahar Bilgen, "Mısır'da Bir Sosyal Devrim Hikâyesi: Urabi Hareketi" Journal of Historical Studies, S. I: C.4, İstanbul 2006, s.15; "Misır'daki borçlanma ve ortaya çıkan kredilendirme riskleri karma mahkemelerin en önemli zeminini oluşturmaktadır" Ezzel-Arab, Abdel Aziz, "The Experiment of Sharif Pasha's Cabinet (1879): An Inquiry into the Historiography of Egypt's Elite Movement", International Journal of Middle East Studies, V: 36, I: 4, Cambridge 2004, s. 561589.

${ }_{58}$ Cannon, Byron David, "Nubar Pasha, Evelyn Baring and a Suppressed Article in the Drummond-Wolff Conventi- on", International Journal of Middle East Studies, V: 5, I: 4, Cambridge 1974, s. 470-475.

${ }^{59}$ İs-Sanafiri, agt, s. 83.

${ }^{60}$ Özer, agt, s. 208; Pınar, age, s. 113.
} 
diplomasi ile Sultan Abdülaziz'e 1 milyon, Sadrazam Fuad Paşa'ya ve diğer Devlet adamlarına verilmek üzere de 600. 000 lira "hediye" eden İsmail Paşa ${ }^{61}, 10$ Haziran 1873/13 Rebiülâhır 1290 tarihli fermanı çıkarttırmayı başarmıştır. ${ }^{62}$ İsmail Paşa, kendisine şimdiye kadar verilen bütün fermanları, 10 Haziran 1873 fermanında, "ahkâmı müstemirren cari olmak" suretiyle toplatmıştır. $^{63} \mathrm{Bu}$ ferman, Osmanlı Devleti’nin Mısır üzerindeki idarî, siyasî ve hukukî hükümranlığını sona erdirecek süreci başlatmada bir kilometre taşı olmuştur. ${ }^{64} \mathrm{Bu}$ ferman, İsmail Paşa'ya yabancı devletlerle anlaşma yapabilme hakkı vermesi ile sebebiyle de batılı devletlerin Mısır üzerindeki etkilerinin artmasında önemli bir etken olmuştur. ${ }^{65}$ Milner, bu ferman için, 1873 büyük fermanı değerlendirmesini yapar ${ }^{66}$. Bu fermanın büyüklüğünün nedeni, şüphesiz ki İsmail Paşa'ya bahşettiği hükümranlık haklarıdır. İsmail Paşa, bu ferman ile sahip olduğu hareket ve faaliyet alanını alabildiğince genişletmiş, yeni bir konum elde etmiştir. Bundan sonra İsmail Paşa, "Babıâli ve yabancı ülkelerle olan ilişsilerinde 1873 fermanını esas alarak hareket etmeye başlamıştır. Bu nedenle 1873 fermanı, Mısır'in anayasası niteliğindedir". ${ }^{67}$ Yine İsmail Paşa bu fermanla, 1866 fermanında olduğu gibi ordusunun sayısını istediği kadar arttırmak imtiyaza sahip olmuş ${ }^{68}$ ve kendini sınırlayan kuralların çok önemli bir kısmından kurtulmuştur. ${ }^{69} \mathrm{Bu}$ yeni imtiyazların İsmail Paşa'ya bahşettiği davranış biçimi Sultan Abdülaziz başta olmak üzere Osmanlı devlet adamlarını oldukça rahatsız edecektir. ${ }^{70}$ İsmail Paşa'nın böyle bir davranış biçimine girmesinde Osmanlı yönetiminin yanlış politikaları oldukça etkili olmuştur. ${ }^{71}$ Çünkü devlet, “... en vasi' imtiyâzât itâ buyrulmadan maksad-ı memleket ve ahalinin temin-i esbâb ma'muriyet ve terkıs"i için İsmail Paşa'ya bu imtiyazları vermiş, "hayfa ki bu ümidler hâ'iz-i fiile çıkamamış ve Devlet-i 'aliyyenin işbu kut'â-i mühimmesi vukû'a gelen su'i idâreden dolayı harâbîyyet-i tammeye düçâr olmakda bulunmuştur,"72.

\section{Mısır Veraset Sistemi Değişiyor: Hıdiviyet'in Doğuşu}

İsmail Paşa, kardeşi Mustafa Fazıl Paşa ve amcası Halim Paşa arasındaki rekabetten çekindiği için Mısır'daki otoritesini kuvvetlendirme düşüncesiyle veraset sistemini değiştirmek istemiştir. Babıâli nezdinde Mısır imtiyaz fermanını genişletmek için İstanbul'u her ziyaret

\footnotetext{
${ }^{61}$ Mustafa Gençoğlu, İngiliz Hâkimiyetinde Misır (1882-1914), (Hacettepe Üniversitesi Sosyal Bilimler Enstitüsü, Yayınlanmamış Yüksek Lisans Tezi), Ankara 1997, s. 30.

62 “Bir rivayete göre, Paşa'nın İstanbul'da, para ve hediye olarak harcadığının toplamı üç milyon liraya ulaşmıştır. Lütfi tarihine göre Pașa'nın "İstanbul'da savurduğu meblağlar hesaba sığmazdl” İs-Sanafiri, agt, s. 47.

${ }^{63}$ Süleyman Kâni İrtem, Osmanlı Devleti'nin Misır Yemen Hicaz Meselesi, Haz: Osman Selim Kocahanoğlu, Temel Yayınları, İstanbul 1999, s. 44.

${ }^{64}$ Şam, agt, s. 54.

65 John Eliot Bowen, Conflictof East and Westin Egypt, G.P.Putnam's Sons, Newyork and London,1887, 23.

${ }^{66}$ Milner, age, s. 36.

${ }^{67}$ Kiziltoprak, age, s. 33.

${ }^{68}$ John P Dunn, Khedive İsmail's Army, London-Newyork 2005, s. 32.

${ }^{69}$ Lowell Joseph Ragatz, The Question of Egypt in Anglo-French Re-lations 1875-1904, Fletcher Pembroke, Edinburgh-Bombay-Sydney 1922, s. 17.

${ }^{70}$ Afaf Lutfi al-Sayyid Marsot, "The Porte and Ismail Pasha's Quest for Autonomy" Journal of the American Research Center in Egypt, V: 12, 1975, s. 90-91.

${ }^{71}$ Mehmed Arif Bey bu durumu şiddetli bir şekilde eleştirmektedir: "Mehmed Ali oğullarının valilikten krallı̆̆a doğru adım adım imtiyazlar kopararak salâhiyetlerini artırmalarl, yürürlükte bulunan verâset usûlünü İsmail Paşa'nın evlâdı lehinde değiştirmeleri, yabancı devletlerden geniş kredi ve borç için izin alabilmeleri ve daha nice yetkilerin hepsi, işte İsmail Paşa denilen bu herifin hiyle ve dolapları, bizimkilerin ise sâfiyet ve ahmakliklar neticesidir" Arif, age, s. 601; "Hıdiv İsmail Paşa'nın Babıâli ile oynadığı hükümdarlık oyunu, Sultan Abdülaziz'in Hıdiv'den bitmez tükenmez istekleri ve Osmanlı Devleti zâafiyetinden ileri gelen Abdülhamid'in Mısır meselesine karşı izlediği tereddütlü siyâseti, Urâbi Paşa ve silâh arkadaşlarının gururu ile bilinçsizliği, Misır'ın kaybedilmesinin en önemli unsurlarl olmuştur" İs-Sanafiri, agt, s. 165.

${ }^{72}$ Y.EE., 116/14.
} 
ettiğinde hediye ve rüşvetlerle bunun zeminini oluşturmaya çalışmıştır. ${ }^{73}$ Sultan Abdülaziz'in Mısır seyahatinde Fuat Paşa ile anlaşan İsmail Paşa, Babıâli’nin mali sıkıntı çektiği dönemde para ve değerli hediyelerle İstanbul'a gelmiştir. ${ }^{74}$

İsmail Paşa, veraset sistemini değiştiren fermanı aldıktan sonra muhtariyet haklarını genişletme faaliyetlerini devam ettirmiş ve hediye diplomasisini etkili bir şekilde yürüterek yukarıda ifade ettiğimiz fermanları almıştır. İsmail Paşa için en önemli ferman ise Hıdiv unvanı aldığ bir düzenleme talep etmiştir. ${ }^{76}$ Bu unvan, Sultan'a denk bir unvandı ve bunun Osmanlı Sultan’1 tarafından kabul edilmesi mümkün değildi. Nubar Paşa, yeniden hediye diplomasisi yürütmeye başlamış ve Fuat Paşa'yı ikna edecek değerde bir hediye ile İstanbul'a gelmiştir. İstediği "Aziz-i Misır" unvanını alamasa da ona yakın bir unvan olan Hıdiv ${ }^{77}$ unvanını almayı başarmıştır. ${ }^{78} 1867$ Fermanı ile Mısır'ı iç işlerinde özerk kılacak yeni düzenlemeler yapılmış ve Mısır'ın Osmanlı Devleti ile olan ilişkileri yeni bir safhaya girmiştir. Zira fermanla İsmail Paşa'nın Mısır iç işlerinde kanun yapma hakkına sahip olduğu vurgulanmıştır. Fakat gümrük işleri ve yabancı devletlerle yapılacak antlaşmalarda padişahın onayını almak zorunda kalsa $\mathrm{da}^{79}$ elde ettiği bu ferman, Hıdiv İsmail Paşa'nın müstakil bir hükümdar gibi davranmaya başlamasının zemini oluşturmuştur ${ }^{80}$. Osmanlı Devleti'nin yanlış politikaları ve Mısır ile girilen hediye diplomasisi sonucu Hıdiv İsmail Avrupa ile yakınlaşacak politikalar sergilemiştir $^{81}$.

\section{Sebepleri \\ Süveyş Kanalının Açılması: Mısır'ın Osmanlı Devleti’nde Kopuşunun İktisadî}

Süveyş Kanalı'nın açılması şüphesiz İsmail Paşa döneminin en önemli olaylarından biridir $^{82}$. Kanalın açılması, Mısır'in uluslararası politika konusu haline gelmesine neden olmuştur. Zira bu kanal, Misır'ın konumunu oldukça etkilemiştir. ${ }^{83}$ İsmail Paşa'nın tamamlayıp açılışına nail olduğu bu kanal, Mısır ekonomisini belirsizliğe sürüklemiştir. Bunun yanında, Mısır tarihinin kaderini değiştirecek gelişmelere de zemin hazırlamıştır. Zira Süveyş Kanalı'nın Napolyon'un Mısır seferinde Ahmed Arabî Paşa'nın Tel El-Kebir hezimetine kadar

${ }^{73}$ Karal, age, s. 41.

74 "Abdülhamid Şehzadeliğinde mehtaplı bir gecede saraya külçeler halinde altın getirildiğini söyler." Süleyman Kani Ertem, “Saray ve Babıali'’nin İç Yüzü", Akşam Gazetesi, Tefrika No: 395, s. 8.

75 “İsmail Paşa'nın “Aziz” unvaniyla anılmak istemesinin temel nedeni, Mısır'da istiklal ile hükmetmiş Yusuf peygamberin mertebesine kendisinin ihraz eylediğini gösterebilmektir”. Karal, age, s. 43.

${ }^{76}$ Karal, age, s. 43.

77 "Mehmet Ali Paşa döneminde toplanan divan "Hıdiv Divanı" olarak adlandırıllyordu. Dolayısıly, hıdiv unvanı rastgele seçilmiş bir unvan değildi. Mehmet Ali Paşa döneminden beri kullanılan, fakat Osmanl Imparatorluğu'nun resmi olarak Mısır valilerine tevcih etmediği bir unvandı. Ayrıca, bazı kaynaklar Ismail Paşa'ya hıdiv unvanının verilerek, Mısır'ın iç işlerinde özerk bir statü kazanabilmesinin nedeninin, Abdülaziz ile Paşa arasındaki ailevi bağdan kaynaklandığın dile getirmektedirler. İsmail Paşa'nın annesi Hoşyar'ın, Abdülaziz'in annesi Pertevniyal Valide Sultan’ın kuz kardeşi olduğu dile getirilmektedir”. Özge Özkoç, Imparatorluk İktidarının Sınırında Osmanlı Mısırı: Mehmet Ali Paşa Döneminden Hıdivliğe, (Yayınlanmamış Doktora Tezi), Ankara 2013, s. 175.

${ }^{78}$ Pınar, age, s. 39; Özkoç, agt, s. 175.

${ }^{79}$ Özkoç, agt, s. 176.

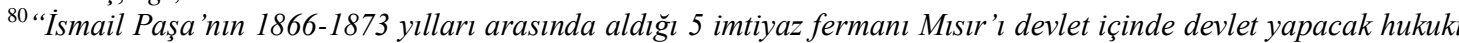
zemini hazırlamışıtır. İsmail Paşa bu fermanlara dayanarak adeta yeni bir Mısır yaratmıştır. Bu fermanlar İsmail Paşa'yı veraset sisteminden dış ilişskilere, idarî yapılanmadan adli teşkilata kadar hemen her alanda yetkili kılacak hukuki şartları oluşturmuştur" Gümüş, age, s. 13.

${ }^{81}$ Pınar, age, s. 41-43; Gümüş, age, s. 15.

${ }^{82}$ Gümüş, age, s. 97.

${ }^{83}$ Donald Malcolm Reid, "Cultural Imperialism and Nationalism: The Struggle to Define and Control the Heritage of Arab Art in Egypt”, International Journal of Middle East Studies, V: 24, I: 1, Cambridge 1992, s. 58. 
İngilizlerin politik stratejilerinin ana unsurlarından biri olmuştur. ${ }^{84}$

Süveyş'e kanal açılması işi Mehmed Ali Paşa ve I. Abbas Paşa dönemlerinde de gündeme gelmiş̧i. Mehmed Ali Paşa ve Abbas Paşa, Süveyş’te kanal açılması fikrine muhalefet etmişlerdi. ${ }^{85}$ Süveyş Kanalı'nın stratejik öneminin farkında olan Mehmed Ali Paşa'nın "Boğazlar Devlet-i Aliye'nin felaketine sebep oldu. Ben de Misır'da bir boğazlar meselesi ihdas etmek istemem" diyerek kanalın açılmasına muhalefet ettiği söylenir. ${ }^{86}$ Ancak Said Paşa, baba ve dedesi gibi düşünmüyordu. $\mathrm{O}$, bu kanal projesine sıcak bakıyordu.

“Süveyş Kanalı'nın mûcidi ve mü'essisi” olan Mösyö Lesseps ${ }^{87}$ Said Paşa döneminde Kahire'nin Fransız konsolosluğu görevinde bulunmuştu. Ferdinand de Lesseps, burada görevli bulunduğu sırada Said Paşa ile iyi ilişkiler kurarak onunla dost olmuştu. ${ }^{88}$ Ferdinand de Lesseps, Said Paşa'nın Misır Valisi olduğunu duyar duymaz buraya gelmiş, Said Paşa ile görüş alışverişinde bulunarak Süveyş’te bir kanal açılması projesini Said Paşa'ya sunmuş ve kanalın açılmasını teklif etmişti. ${ }^{89}$ Said Paşa tarafında, dostu De Lesseps'in bu teklifini kabul ederek kanalın yapılması çalışmalarına başlanılması için gerekli zemin oluşturulmuştur. ${ }^{90}$ Kanalın hafriyatı için ilk ruhsat 30 Kasım 1854'de verilmiştir. ${ }^{91}$

İsmail Paşa, valiliğe atanması dolayısıyla geldiği İstanbul'da İngiliz elçisi ile görüşme imkânı bulmuş, Süveyş Kanalı konusunu gündeme getirmiş ve bu görüşmede, kanal için verilen 1854 ve 1856 imtiyazların tadil edilmesi kararlaştırmışlardır. ${ }^{92}$ İsmail Paşa, Nubar Paşa'yı Mısır'a döner dönmez Lesseps ile kanalın yeni şartlarını görüşmek üzere Paris'e göndermiş, Nubar Paşa da, Paris'ten İngiltere, Fransa ve Lesseps arasında 22 Şubat 1866 tarihli mukavelename ile dönmüştür. Şimdi ise sözleşmenin Sultan Abdülaziz tarafından tasdik edilip anlaşmanın resmiyete geçirilmesi gerekiyordu. ${ }^{93}$ Sultan Abdülaziz'in tasdiki de 19 Mart 1866 tarihli ferman ile söz konusu olmuştur ${ }^{94}$ İsmail Paşa, için en önemli mesele ise bu kanalın

${ }^{84}$ Donal Scott Buchanan, The British Invasion Of Egypt And The Political Press, Submitted to the Graduate Faculty of Texas Tech University in Partial Fulfillment of the Requirements for the Degree of Master Art, Teksas 1997, s. 26-27.

${ }^{85}$ Gençoğlu, agt, s. 43.

${ }^{86}$ Zeynep Güler, Süveyș 'in Batısında Arap Milliyetçiliği Mısır ve Nasırcılık, Yenihayat Kütüphanesi, İstanbul 1994, s. 43; İrtem, age, s. 36; Hayrettin Pınar, Babıâli ve Hıdiv İsmail, Kitap Yayınevi, İstanbul 2012, s. 16; Gümüş, age, s. 99.

87 İ.HR., 257/15357.

88 "Ata binmeyi ve nişancllk mümareseni Ferdinand de Lesseps'ten öğrenen Said Paşa, şişman olduğu için babası tarafindan siku bir perhize tabi tutulduğu siralarda Ferdinand de Lesseps'in teşvikiyle makarnaya rağbet göstermeye başlamıştı. Makarna tabağıyla pekiştirilen bu dostluk, tüm dünyayı hayran bırakarak uluslararası bir mücadeleye neden olacak olan Süveyş Kanalı'nın açılmasına vesile olmuştur" Tuba Çınar, "Süveyş Kanalı'nın Açılması ve Osmanlı Dış Politikasındaki Önemi 1869-1882, (Gazi Üniversitesi Sosyal Bilimler Enstitüsü, Yayınlanmamış Yüksek Lisans Tezi), Ankara 2008, s. 73.

${ }^{89}$ Güler, age, s. 44.

90 Bell, K, "British Policy Towards the Construction of the Suez Canal (1859-65)", Transactions of the Royal Historical Society, 5th Ser, V: XV, 1965, s. 121.

${ }^{91}$ D. Mackenzie Wallace, Egypt and The Egyptian Question, Macmillan And Co, London 1883, s. 329-330; Ragatz, age, s. 12.

${ }^{92}$ Çünkü 1856 kanal sözleşmesinin ihtiva ettiği hukukî durum, kanal şirketi oldukça imtiyazlı bir duruma getirmişti. $\mathrm{Bu}$ hali ile "...devlet içinde bir devlet durumunda bulunuyordu. Deniz kanalı ile ona bağll tatlı su kanalları kenarında ele geçirmiş olduğu topraklar sayesinde, Mısır'ın arâzisi içinde bir nevî müstemleke kurmuş idi" Sabry, M, "Nubar Paşa", MEB İslam Ansiklopedisi, C. IX, Millî Eğitim Basımevi, İstanbul 1964, s. 338; Gümüş, age, s. 105.

${ }^{93}$ Khosrow Mostofi, “The Suez Dispute: A Case Study of a Treaty”, The Western Political Quarterly, V: X, I: 1, 1956, s. 25-26.

${ }^{94}$ Akalın-Parlaz, agt, s. 67; İs-Sanafiri, agt, s. 43. 
yapımı için mali kaynak bulmaktı ve bu hiç de az bir miktar değildi. ${ }^{95}$ İsmail Paşa bu meseleyi de hallederek kanalı, 1869 yılında açılacak hale getirdi. ${ }^{96}$ Kanalın açılışı ise İsmail Paşa için bir gövde gösterisi şeklinde tezahür etmiş, şatafatlı bir açılış töreni organize edilmiştir. ${ }^{97} \mathrm{Bu}$ tören, tam bir şov şeklinde icra edilmiştir. ${ }^{98}$ Bunun yanında, Süveyş Kanalı'nın açılış töreni gününde bitirilecek şekilde inşa edilen diğer bütün yapılar misafirlerin gözünü kamaştırmıştı. Davet edilen misafirler arasında ise oldukça önemli isimler vard1 ${ }^{99}$. İsmail Paşa, bunu başarmak için milyonlar sarf etmiş, Mısır hazinesine yeni yükler yüklemiştir ${ }^{100}$. Bu yapıların maliyeti kısaca hesaplandığında Mısır maliyesinin içine düştüğü buhran net bir şekilde anlaşılmaktadır ${ }^{101}$. Bunun yanında inşa ettirdiği demiryolları, telgraf sistemleri ve limanların maliyeti de hesaplandığında Hıdiv İsmail Paşa'nın Mısır'ın maliyesini nasıl bir iktisadî buhrana sürüklediği anlaşılmaktadır. ${ }^{102}$ Misır'da mali buhran ve Mısır'ın mukadderatını etkileyen konuların başında Süveyş Kanalı gelmektedir ${ }^{103}$.

\section{Sonun Başlangıcı: Mısır Malî Buhranı ve Hıdiv İsmail Paşa'nın Azli}

İsmail Paşa'nın Mısır'da sebep olduğu değişim, Mısır için en azından 19. asrın bütün kazanımlarını tehlikeye atmıştı. Bunun anlamı şuydu; Mısır, özellikle Mehmed Ali Paşa ile giriştiği modernleşme atılımlarının etkilerini birçok sahada görmüş, önemli bir gelişim göstermişti. Varidat artmış, göreceli bir refah dönemi söz konusu olmuştu. Ancak İsmail Paşa ile ileri seviyelere ulaşan israf ve anlamsız yatırımlar Mısır'ın maliyesini mahvetmiş, alınan borçlar ve hediye diplomasisi Mısır'ı mali açıdan geri dönülemez bir yola sokmuştu. İsmail Paşa'nın kişisel hırsı da bu durumu oldukça nazik bir safhaya taşımıştı. Bunun iki önemli sonucu oldu. Birincisi Mısır'ın Osmanlı Devleti'ne olan bağı zayıflamış, ikinci olarak da Mısır büyük devletlerin güdümüne girerek işgale uğramış ve bağımsızlığını yitirmiştir. Bütün bunların oluştuğu dönem, İsmail Paşa'nın Mısır Valiliği, sonrasında da Hıdivliği dönemidir. İsmail Paşa dönemi ile birlikte İngiltere ve Fransa, Mısır'ın bütün işlerine müdahale etmişler, bütün karar, kanun ve düzenlemelerinde söz sahibi olmuşlardır. Dolayısıyla Mısır, Avrupa

${ }^{95}$ F. Robert Hunter, "Egypt Under the Successors of Muhammad‘ Ali" The Cambridge History of Egypt, V: 2, Modern Egypt, From 1517 to The End of the Twentieth Century, Ed: By M. W. Daly, Cambridge 1998, s. 189.

${ }^{96}$ W. Basil Worsfold, The Future Of Egypt, Collins Clear Type Press, London, s. 40.

97 "Hıdiv ismail, Mısır'ın artık Afrika'nın bir parçası olmadığını, uygar Avrupa dünyasına mensup olduğunu göstermek için bu firsattan yararlandl. Açıllşa katılan davetliler arasında, Avusturya imparatoru, III. Napolyon'un karısı Imparatoriçe Eugenie, Prusya Veliaht Prensi, Fransız sanatçıları ve yazarları -Theophile Gautier, Emile Zola, Eugene Fromentin- Henrik Ibsen, tanınmış bilimciler ve müzisyenler yer aldı. Törenleri Müslüman ve Hıristiyan din adamları yönetti ve Imparatoriçe bir kraliyet yatı ile yeni kanala ilk kez giren teknelerin başını çekti" Albert Hourani, Arap Halkları Tarihi, Çev: Yavuz Alogan, iletişim Yayınları, İstanbul 2009, s. 334-335.

98 İsmail Paşa, bu şova, Avrupa'nın önde gelen simalarını Süveyş Kanalı'nın açılışına davet etmek için gittiği Avrupa seyahatinde başlamıştı: "Hıdiv, Süveyș Kanalı'nın açılışı bahanesi ile çıktı̆̆ Avrupa seyahati boyunca müstakil bir hükümdar gibi hareket etti. Gittiği her ülkede de kendini müstakil bir hükümdar gibi sundu. İtalya, Avusturya, Ingiltere ve Fransa'ya giderek bizzat hükümdarları ve hükümet başkanlarını kanalın açılış merasimine davet etti. Buralarda da sürekli destek arayışlarına girişti. Devletlerden farklı farklı farkl muameleler gördü" İsSanafiri, agt, s. 77; Bu şovu gerçekleştirirken de Osmanlı Devleti'nin Mısır'daki hükümranlık haklarını bir bir çiğniyordu: "1869 yılında, Süveyş Kanalının resmî açılışının debdebeli bir şekilde yapılması ve Padişahın hükümranlı haklarına aykırı olarak onun gıyabında Avrupa hükümdarları veya hükümdar mümessillerini kendi kendine bu törene çă̆ırması, Osmanlı Devleti'nin kızgınlı̆̆ım daha da arttırdı. Eski imtiyazlara yemden sahip olmak isteyen İsmail Paşa, tekrar Avrupa devletlerinden destek arayışına teşebbüs etti” Namık Sinan Turan, Imparatorluk ve Diplomasi, İstanbul Bilgi Üniversitesi Yayınları, İstanbul 2015, s. 413-414; Şam, agt, s. 53.

${ }^{99}$ BOA, A. DVNSMSR.MHM.d, 15/45.

${ }^{100}$ Sir Samuel W Baker, Ismailia a Narrative Of The Expedition To Central Africa For The Suppression Of The Slave Trade, V: I, Macmillan And Co, London 1874, s. 19; Marsot, age, s. 68-69.

101 İsmail Paşa döneminde Mısır'ın borçları 3-4 milyondan 100 milyona yükselmiştir. İ. MTZ (05)., 22/957.

${ }^{102}$ Donalt Featherstone, Tel-El Kebir Wolseley's Conquest of Egypt, Great Britain 1993, s.7.

${ }^{103}$ Geniş Bilgi için Gümüş, age, s. 108-116. 
devletlerinin ekonomik ve siyasi güdümüne girmiştir. ${ }^{104}$ Bunun en önemli sebebi ise İsmail Paşa'nın kişisel hırsı dolayısıyla kurduğu ilişki biçimi ve bunun sebep olduğu siyasî ve ekonomik atmosferdir ve Mısır'ı kapitalizm ve emperyalizmin kontrolüne düşürmüştür.

İngiltere'nin siyasi ve ekonomik çıkarları, Süveyş Kanalı'nın mukadderatını etkilemiştir. ${ }^{105}$ Zira Mısır'ın İngiltere tarafından işgal edilmesinde Süveyş Kanalı İngiltere'ye çok önemli gerekçeler oluşturmuş ve kanalın kontrolünün Mısır'ın elinde olmayacak bir seçenekle, yeni bir statükoya kavuşturulmasının önü açılmıştır. ${ }^{106}$ İngiltere, bunun için ortaya çıacak her gelişmeyi firsata çevirmek için sabırlı bir diplomasi sergilemiştir. En önemlisi ise geleneksel çıkarlarını korumak için çareyi Süveyş Kanalı ve etrafındaki bölgeleri kontrolü altında tutmasıdır ${ }^{107}$ Bunun için en önemli fırsat ise İsmail Paşa tarafından satılığa çıkartılan Süveyş Kanalı hisselerine sahip olmaktı. 23 Kasım 1875 tarihinde bu firsat zuhur etmiş ve hisselerin \%44'lük bir kısmını yaklaşık 4 milyon Pound karşılığında almıştır. ${ }^{108} \mathrm{Bu}$ satış, Mısır'ın Süveyş Kanalı'ndaki üstün konumunun sona ermesi anlamını taşıyordu. İsmail Paşa, Süveyş Kanalı'nın hisselerini satarak stratejik açıdan büyük bir hata yapmıştır. ${ }^{109}$ Yine bu satış, Mısır'da işgal sürecinin yolunu açmıştır. ${ }^{110}$

İsmail Paşa'nın Süveyş Kanalı'nın hisselerini, “ihtiyaçtan” dolayı İngiltere'ye satması, Mısır'ın Osmanlı Devleti'nin elinden çıkış sürecinin başlangıcını teşkil etmiştir. ${ }^{111}$ Burada ortaya konulan İngiliz politikaları, başta Osmanlı Devleti olmak üzere diğer devletlerin elini kolunu bağlamıştır. Bu da, İngiltere'nin Mısır ve Süveyş üzerindeki tasavvurlarını daha rahat bir şekilde gerçekleştirmesini sağlamıştır.

İsmail Paşa'nın Mısır'da ortaya koyduğu yanlış politikaların sonuçları yavaş yavaş ortaya çıkmaya başlamıştır. Özellikle Mali durumda meydana gelen bozulma ve alınan borçların ödenememesi, alacaklı devletlerde bir hareketliliğe sebep olmuştur. Bu, İsmail Paşa'nın kendi sonunu hazırladığını göstermekteydi. İsmail Paşa, bu durumu "düzeltmek" için yeni uygulamaları devreye sokmaya karar verdi. Zaten İngiltere ve Fransa, Misır'da bir reform

${ }^{104}$ Kiz1ltoprak, agt, s. 35.

105 İngiliz devlet adamları Süveyş Kanalı'nın önemini ve Mısır'a kattığı değeri birçok kez dile getirmişlerdir: "Liberal politikacılardan Charles Dilke, emperyalist bir politikacı olarak Süveyş Kanalı'nın tehlikede olduğunu ileri sürerek Misır'in işgal edilmesi gerektiğini düşünenlerdendi. Gladstone'un Mısır politikalarındaki önemli destekçilerinden biri Dilke idi. Daha 1868 yılında yayınlamış olduğu "Daha Büyük Ingiltere'nin Problemleri" başlıklı çalışmasında; "Kanal, evimizin yoludur. Burayı kaybetmek Hindistan ve Çin ticaretinin bizler için ölümcül sonuçlarının ortaya çıkması anlamına gelir" yaklaşımıyla Mısır'ın mutlaka elde edilmesi gerektiğini söylüyordu. Dilke'nin düşünceleri aynı şekilde Gladstone tarafından da dile getiriliyordu. Örneğin Gladstone, Lord Ripon'a gönderdiği bir mektupta; "Mısır'ın ve kanalın Ingiliz çıkarları için ne denli önemli olduğunu, Ingiltere'nin bu çıkarları için Misır ile ilgilenmesi gerektiğini” ifade ediyordu“... dış işleri bakanı Lord Stanley bir nutkunda "Kanal üzerinde yapılacak ticaretten hiçbir millet bizim milletimiz kadar istifade etmiyecektir" diyerek kanalın değerini belirtiyordu" İs-Sanafiri, agt, s. 43; "İngilizlerin Mısır'daki çıkarı, tahvil sahiplerinin yanı sıra, o dönemde artık Hindistan'daki hâkimiyet alanlarına giden bir cankurtaran halatı olan Süveyş Kanalı idi” Marsot, age, s. 75.

106 “'Mısır ve Kıbrıs'ın işgali, Ingiltere'nin artık Ortadoğu'ya yerleşme planların yürürlüğe soktuğunu ve öncelikle stratejik noktaları işgal edeceğini göstermiştir. Bu gelişmeler Ortadoğu'da Türk hâkimiyetinde bulunan diğer bölgelerde çeşitli tedbirlerin alınmasını zorunlu kılmıştır” Yılmaz, age, 54.

${ }^{107}$ W. Eathbone, Great Britain and The Suez Canal, Chapman\&Hall, London 1882, s. 3; Güler, age, s. 61.

${ }^{108}$ Hunter, age, s. 195; J. C. Mccoan, Egypt, With A Supplementary Chapter Of Recent Events, Peter Fenelon Collier, New York 1893, s. 270; Sir Arnold T Wilson, Suez Canal its Pasty Present, and Future, Second Edition, Oxford University Press, London 1939, s. 58.

${ }^{109}$ Bent Hansen-Khairy Tourk, "The Profitability of the Suez Canal as a Private Enterprise, 1859-1956", The Journal of Economic History, V: 38, I: 4, Cambridge 1978, s. 957.

${ }^{110}$ Arif, age, s. 618.

111 'İsmail Paşa, vükela ve Avrupa'nın lehine (Avrupa'yı arkasına almak gayesiyle) sarf ettiği parayı kazanmak için Süveys Kanalı hisselerini Ingiltere'ye sattı. Bu șekilde bağımsızlı̆̆ını kazanmak istediği mülkün anahtarını “'Misır' '’' Ingiltere'ye vermiş oldu”'(Y.EE. 9/37); Gümüş, age, s. 113-114. 
sürecinin başlamasını istemişler ve bununla ilgili olarak da Tahkikat Komisyonu kurulmuştu. Temel amaç, Mısır'ın dış borçlarını ödeyebilecek bir mali yapıya kavuşturulması idi. ${ }^{12}$ Ancak Mısır maliyesinin açığı 10 milyon liraya yakındı. Bundan da İsmail Paşa sorumlu tutulmuş ve kendi emlak ve gelirlerinin Misır lehine terk etmesi lüzumlu görülmüştür. ${ }^{113}$

İsmail Paşa'nın Mısır' da ekonomik olarak kontrolü elden kaçırması sonrasından durumu düzeltmek üzere çeşitli girişimlerde bulunmuştur. Bunlardan biri, İngiltere'den bir müfettiş istemesidir. İngiltere, İsmail Paşa'nın bu talebini Stephen Cave'i Mısır'a göndererek karşılamıştır. ${ }^{114}$ Ancak Cave'in çalışmaları ve hazırladığ ${ }_{1}$ rapor, Mısır ekonomisinin felaket durumunu gözler önüne sermiştir. Bu, İsmail Paşa'nın hoşuna gitmemiş hatta bunda bir maksat aramıştır. ${ }^{115}$ Cave'in raporu Mısır'ın bu hale gelmesinde Avrupalı finansörlerin de güçlü bir payı olduğunu ortaya koyuyordu. ${ }^{116}$ Ancak durum, Cave'in raporundaki gibiydi ve önlem alınması talep ediliyordu. ${ }^{117} \mathrm{Bu}$ rapor, Mısır maliyesinin iflas ettiği ve borçlarını ödeyemeyecek durumda olduğunu ortaya koyuyordu. ${ }^{118}$ Misır maliyesi çökmüştü ve bu hali ile tam bir hayal kırıklığını ifade ediyordu. ${ }^{119}$

İsmail Paşa ise bu durumdan, o an için kurtulmak amaciyla Nubar Paşa'ya bir kabine kurması görevini vererek meşruti yönetime geçtiğini ilan etmesi olmuştur. ${ }^{120} \mathrm{Bu}$ tedbir, İsmail Paşa'nın içinde bulunduğu durumdan kurtulmaktan başka bir şey değildi ve ${ }^{121}$ kabinenin İngiliz ve Fransızların Mısır'ın yönetimine ortak olması anlamına geliyordu. Çünkü kabinede, Maliye Nezareti'ne İngiliz River Wilson, Nafia Nezareti'ne de Fransiz De Blignieres atanmıştı. ${ }^{122}$ River Wilson De Blignieres, Mısır'da mâlî denetleyen üst yapı konumunda tanzim edilmişti. İngiliz ve Fransız Nazırların Mısır kabinesindeki konumları Mısır'da önemli bir iç huzursuzluğa sebep olmuştur. ${ }^{123}$ İsmail Paşa da bu hoşnutsuzluğu bertaraf etmek için Nubar Paşa'yı azlederek oğlu Mehmed Tevfik Paşa başkanlığında yeni bir bakanlar kurulu oluşturmuştu. ${ }^{124}$ İngiltere ve Fransa bu yeni duruma tepki göstermişlerdir.

İsmail Paşa'nın Mısır'da hareket alanı gün geçtikçe daralmaya başladı. Bu da İsmail Paşa'nın üstündeki baskının artması anlamına geliyordu. İsmail Paşa, içinde bulunduğu durumdan kurtulmak için Babıâli'ye başvurmak zorunda kaldı. Ancak İstanbul'da tutunacak bir dalı kalmamıştı. ${ }^{125}$ Azledilmekle karşı karşıya kaldı. Salisbury’nin de Hıdiv İsmail Paşa'nın

\footnotetext{
${ }^{112}$ Lieut Colonel Hennebert, English in Egypt England and The Suez Canal, (Translate by Permission By Bernard Pauncefote), Allen \&Co Press, London 1884, s. 33.

113 İs-Sanafiri, age, s. 112.

${ }^{114}$ Hunter, age, s. 24; Gümüş, age, s. 19.

${ }^{115}$ Taha Niyazi Karaca, Büyük Oyun, Timaş Yayınları, İstanbul 2011, s. 428.

${ }^{116}$ Wildfrid Scaven Blunt, Secret History of English Occupation Of Egypt, Vail-Ballou Co, New York 1922, s. 1617.

${ }^{117}$ H. D Traill, Lord Cromer, Bliss, Sands and Co, London 1897, s. 21; Dicey, age, s. 140.

${ }^{118}$ Traill, age, s. 22; Gümüş, age, s. 19-20.

${ }^{119}$ Traill, age, s. 27.

${ }^{120}$ Traill, age, s. 28.

${ }^{121}$ Şam, agt, s. 56-57.

122 "Hem Fransa hem Ingiltere yıllardır Misır ile ilgileniyorlardı ve Misır'in mali durumunun bozulması Valiyi bir Ingiliz'i Maliye Bakanı ve bir Fransız'ı [da]Bayındırlık Bakan yapmaya zorlamalarına imkân verdi” Jame Grant, Cassell's History Of England From The illness Of ThePrince Of Wales To The British Occupation Of Egypt, V. VII, Cassell And Company, Limited, London 1909, s. 574; Mostofi, agm, s. 26-27; Traill, age, s. 35; Gümüş, age, s. 23.

${ }^{123}$ Ann Elizabeth Mayer, Abbas Hilmî II: The Khedive and Egypt's Struggle For Independence, V. I, Michigan: A Dissertation Submitted in Partial Fulfillment of The Requirements For The Degree Of Doctor of Philosophy,1978, s. 5.

${ }^{124}$ Traill, age, s. 35.

125 “İsmail Paşa Mısır içerisinden de önemli ölçüde destek kaybetmişti: İsmail Paşa'nın azlini sağlamaya yönelik Mısır içerisinden de çeşitli teşebbüsler olmuştu. Özellikle Cemâleddin Efgâni'den etkilenen bazı reformcu Ezherliler, onun azli için çalışıyorlardı "İs-Sanafiri, agt, s. 117.
} 
azledilmesini desteklemek konusunda tereddüdü kalmayınca azli an meselesiydi. ${ }^{126}$ Ancak asıl mesele azlin nasıl gerçekleşeceği idi. Çünkü hem İngiltere-Fransa hem de Osmanlı Devleti İsmail Paşa'nın azlinden sonra oluşacak yeni düzenin kendi kontrollerinde şekillenmesini istiyorlardı. Bu da İsmail Paşa'nın yerine kimin geçeceği ile alakalı bir şeydi. Zira Fransa ve İngiltere İsmail Paşa'nın oğlu Mehmed Tevfik Paşa'nın ${ }^{127}$, Sultan II. Abdülhamid de Mehmed Ali Paşa'nın oğlu Halim Paşa'nın Mısır Hıdivi olmasını istemekle ${ }^{128}$ birlikte Mısır'a verilmiş imtiyazları da kaldırılmaya çalışıyordu. ${ }^{129}$ İmtiyazların kaldırılması Osmanlı Devleti’nin Mısır'daki konumunun etkin bir hale getirilmesi için gerekliydi. Bu sırada da Mısır'daki vaziyet İsmail Paşa'nın kontrolünden çıkmıştı. İç muhalefet hoşnutsuzluğunu açık bir şekilde göstermekteydi ve buhran halini daha da ağırlaşmaya başladı. ${ }^{130}$ İsmail Paşa'nın yabancı nazırları azledip yeni kabineyi Şerif Paşa Şerif Paşa'ya kurdurmas ${ }^{131}$ kendisine karşı oluşan tepkiyi ortadan kaldırmak istemesinden başka bir şey değildi. Bu sırada İngiltere ve Fransa İsmail Paşa'yı istifaya davet ederek Hıdivlikten oğlu lehine çekilmesini istediler. ${ }^{132}$ İsmail Paşa Babıâli'yi kendisine kalkan yaparak Babıâli'den İngiltere ve Fransa'nın bu isteklerini reddetmesini istedi. Ancak Babıâli'nin ve sarayın İsmail Paşa'ya karşı tavrı ve düşünceleri eskisi gibi değildi. İsmail Paşa, büyük hedeflerini gerçekleştirme hırsıyla hareket ederek öncelikle Mısır'ın Osmanlı Devleti ile olan bağını zayıflatmış, arkasında Mısır'ın maliyesini çok kötü bir şekilde yöneterek Mısır'ın bağımsızlığına büyük bir darbe vurmuştur. Bu da Mısır'ın işgalini hazırlamış ve Osmanlı Devleti ile bağının sadece kâğıt üzerinde kalmasına sebep olmuştur. Bunun yanında Mısır halkını oldukça kötü şartlara duçar bırakmıştır. Kendinden sonraya oldukça sorunlu bir Mısır bırakmıştır.

Sultan II. Abdülhamid'in tahta çıkmasında sonra, İsmail Paşa'nın İstanbul nezdindeki durumu değişmişti. Sultan II. Abdülhamid, İsmail Paşa'nın azledilmesini Mısır'da egemenliğin yeniden tesisi için bir firsat olarak görmekteydi. Zaman geçtikçe Abdülhamid'in Halim Paşa'y1 Hıdivliğe getiremeyeceğini anladığından, bu konuda çok ısrarlı olamamıştır. ${ }^{133}$ Babıâli'den de Mehmet Tevfik Paşa'nın Hıdiv olarak atanması kararı çıkmış ${ }^{134}$ ve karar, ilgili dış mercilere bildirilmiştir ${ }^{135}$. Sonuçta, İsmail Paşa 25 Haziran 1879 tarihinde azledilmiş, azil ve Mehmed Tevfik Paşa'nın Hıdivliğe atanması kararı ${ }^{136}$ İsmail Paşa'ya bildirilmiştir. 8 Ağustos 1879 'da Mehmed Tevfik Paşa hıdiv olarak tayin edildikten sonra İsmail Paşa'nın uygulamadan kaldırdığı uluslararası kontrol mekanizmaları daha etkin bir şekilde yeniden kurulmuştur. ${ }^{137}$ İsmail Paşa'nın Mısır'da kalması mahzurlu görüldü ve Mısır'dan sürgün edilmesi kararı çıktı. İstanbul'da kalmak istemesi de "memalik-i mahruse-i şahanenin hiçbir mahallinde ikameti mehazir-i adideyi müstelzim olacağ cihetle riza-i aliye katiyen tevafuk etmeyeceğinden" reddedilmiştir ${ }^{138}$. $\mathrm{Bu}$, onun vatansız kalması demekti. Bu vatansızlık durumu 1895 yılı şubat ayına kadar devam etmiş, oğlunun verdiği sadakat teminatı ile vatanına dönebilmişti.

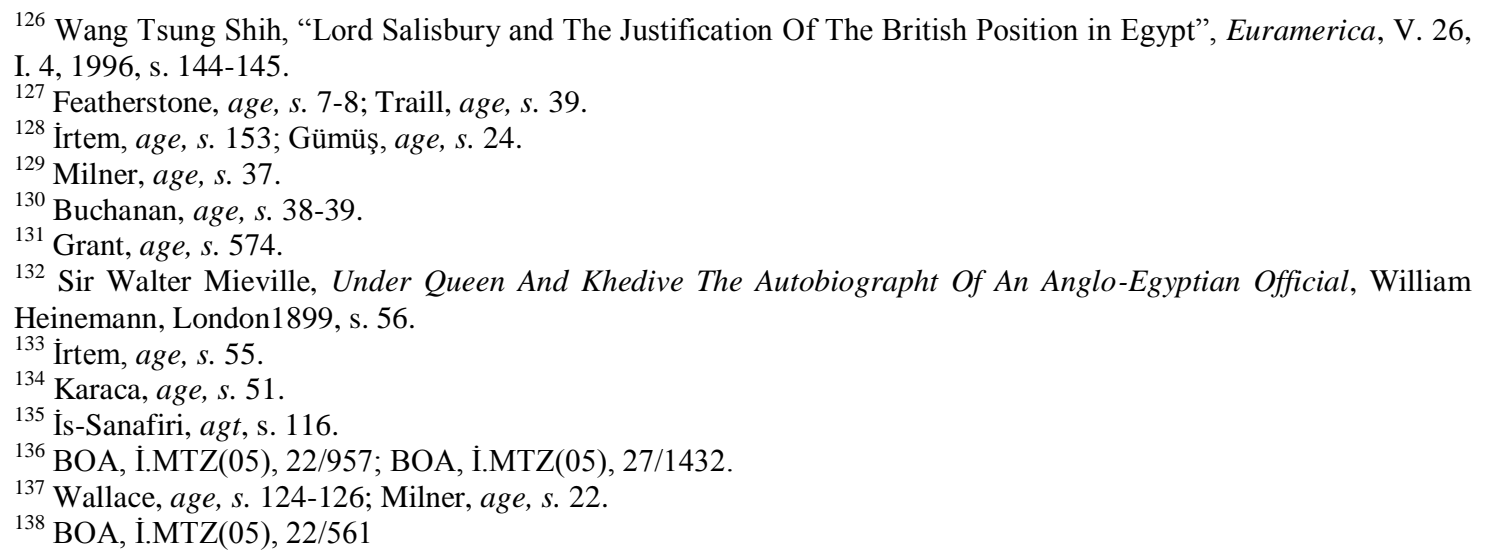


İstanbul'a geldikten kısa bir süre sonra, 2 Mart 1895 tarihinde ölmüştür ${ }^{139}$.

\section{Sonuç}

İsmail Paşa'nın Mısır'a vali olarak atanması, Osmanlı-Mısır ilişkilerinde bir dönüm noktası olarak kabul edilebilir. Onun döneminde Mısır'da büyük değişimleri yaşanmıştır. İsmail Paşa'nın çocukluk döneminde aldığı Avrupai tarzda eğitimin etkisiyle Mısır'da yeni bir atmosferin oluşmasına neden olmuştur. Bu atmosfer, İsmail Paşa'nın Mısır'ı Avrupalılaştırmak düşüncesinin bir sonucu olarak oluşmuş ve Mısır'ın mukadderatının değişmesine sebep olmuştur. Zira İsmail Paşa, Büyük Mısır İmparatorluğu hayalini gerçekleştirmek için Avrupalılaşmak yolunu tutmuştu. İsmail Paşa amacına ulaşmak için Mısır'ın statüsünü değiştirecek ciddi düzenlemeler ihtiyaç duymaktaydı. Bunun için Babıâli ve Saray ile yeni bir ilişki biçimi geliştirmeli ve Mısır'da kendi hareket alanlarını kısıtlayacak zincirlerden kurtulmalıydı. Bu ilişki biçimi bir çeşit hediye diplomasisiydi ve ilişkilerin yakınlaşmasını sağlamış, Babıâli ve Saray'ın gözünde teveccüh kazanmasına imkân vermiştir. Bu yakınlık hediyenin değeri ile sıkı bir biçimde ilişkilidir. İsmail Paşa değerli hediyelerle elde ettiği imtiyaz fermanları ile konumunu oldukça güçlendirmiş ve bunu bağımsız hareket edebilmek için kullanmıştır. Mısır'da elde ettiği serbestliğin sağladığı rahatlıkla izlediği bilinçsiz politikalar, Mısır'ın bağımsızlığının sonunu getiren süreci beslemiştir. 1866-1873 yılları arasında elde ettiği imtiyaz fermanları ile Mısır'daki konumunu güçlendiren İsmail Paşa, kendisini sair Osmanlı valilerinden daha üstün bir mertebeye taşımıştır. Osmanlı Devleti'nin içinde bulunduğu siyasi koşullar da İsmail Paşa'ya firsatlar yaratmıştır. Hediye diplomasisi ile Babıâli üzerinde kurduğu etki, "Hıdiv" unvanının doğuşunu sağlamış ve İsmail Paşa'ya, bir hükümdar gibi davranmasının zeminini hazırlamıştır. Hıdiv olarak yönettiği Mısır'1 yönettiği dönemde Mısır'ın mukadderatını etkileyen birçok meselede sorumsuz tasarruflarda bulunarak Osmanlı Devleti'nin hukukuna ciddi zararlar vermiş ve Mısır'ın işgalini hazırlamıştır. Mısır'ın işgalini hazırlayan meseleler başta ekonomi, hukuk, sosyal, idari ve siyasi olarak çeşitlilik göstermiştir. Bu alanlarda meydana gelen bozulma başta Mısır'ın bağımsızlığına halel getirme olmak üzere çok ciddi sonuçlar doğurmuştur. 1863-1879 yılları Mısır'ın Osmanlı Devleti'nin elinden gitmesinde önemli bir tarih aralığıdır. $\mathrm{Bu}$ yıllar arasında yürüttüğü politikalara Mısır'daki Osmanlı egemenliğini İngiliz egemenliğine tahvil etmiștir. İsmail Paşa'nın Mısır idaresi kendinden sonra çok sorunlu bir Mısır bırakmıştır. Sultan II. Abdülhamid de bu sorunların üstesinden gelmek için çok uğraşmasına rağmen Mısır'daki sürecin yönünü değiştirememiş Mısır kaybedilmiştir.

${ }^{139}$ Tahsin Paşa, Yıldız Hatıraları Sultan II. Abdülhamid, Boğaziçi Yayınları, İstanbul 1999, s. 148; Gümüş, age, s. 25 . 


\section{KAYNAKÇA}

\section{1-Arşiv Belgeleri}

BOA, A. DVNSMSR.MHM.d, 15/45.

BOA, İ.HR., 257/15357

BOA, İ.MTZ (05)., 22/957.

BOA, İ.MTZ(05), 22/561

BOA, İ.MTZ(05), 22/957

BOA, İ.MTZ(05), 27/1432.

BOA, Y.EE, 34/62.

BOA, Y.EE. 9/37.

BOA, Y.EE., 116/14.

BOA, Y.PRK.MK. 1/94.

\section{2- Makale ve Kitaplar}

AKALIN, Durmuş -Selim Parlaz, "Nil'de İktidar Mücadelesi ve Kavalalı", Çankırı Karatekin Üniversitesi Uluslararasi Avrasya Stratejileri Dergisi, C. 1, S. 1, Çankırı 2012.

AKSAN, Virginia H., Kuşatılmış Bir Imparatorluk Osmanlı Harpleri 1700-1870, Çev: Gül Çağalı Güven, İş Bankası Kültür Yayınları, İstanbul 2010.

AKSÜT, Ali Kemal, Sultan Azizin Mısır ve Avrupa Seyahati, Ahmet Sait Oğlu Kitabevi, İstanbul 1944.

ALTUNDAĞ, Şinasi, "İsmail Paşa" Milli Eğitim Bakanlı̆̆ İslam Ansiklopedisi, C. 5/2, Milli Eğitim Basımevi, İstanbul 1974.

ARIF, Mehmed, Başımıza Gelenler, İrfan Yayınevi, İstanbul 1976.

ARMAOĞLU, Fahir, 19. Yüzyıl Siyasi Tarihi, TTK Yayınları, Ankara 2000.

AYBİ, Mahmud, II. Abdülhamid'in Ortadoğu Politikası, (Muğla Üniversitesi Sosyal Bilimler Enstitüsü, Yayınlanmamış Yüksek Lisans Tezi), Muğla 2009.

AZİZ, Ezzel-Arab, Abdel, “The Experiment of Sharif Pasha's Cabinet (1879): An Inquiry into the Historiography of Egypt's Elite Movement", International Journal of Middle East Studies, V: 36, I: 4, Cambridge 2004.

BAKER, Sir Samuel W, Ismailia a Narrative Of The Expedition To Central Africa For The Suppression Of The Slave Trade, V: I, Macmillan And Co, London 1874.

BECKER, Carl H., "Fetihten Osmanlılar Devrine Kadar Mısır", Milli Eğitim Bakanlı̆gl İslam Ansiklopedisi, C. 8, İstanbul 1979.

BELL, K, "British Policy Towards the Construction of the Suez Canal (1859-65)", Transactions of the Royal Historical Society, 5th Ser, V: XV, 1965.

BIGER, Gideon, "The First Map of Modern Egypt Mohammed Ali's Firman and the Map of 1841", Middle Eastern Studies, C. 14, 1978. 
BILLGEN, Bahar, "Mısır'da Bir Sosyal Devrim Hikâyesi: Urabi Hareketi" Journal of Historical Studies, S. I: C.4, İstanbul 2006.

BLUNT, Wildfrid Scaven, Secret History of English Occupation Of Egypt, Vail-Ballou Co, New York 1922.BOWEN, John Eliot, Conflictof East and Westin Egypt, G.P.Putnam's Sons, Newyork and London, 1887.

BUCHANAN, Donal Scott, The British Invasion Of Egypt And The Political Press, Submitted to the Graduate Faculty of Texas Tech University in Partial Fulfillment of the Requirements for the Degree of Master Art, Teksas 1997.

CHIROL, Valentine, "The EgyptianQuestion", Journal of theBritish Institute of International Affairs, V: 1, I: 2, 1922.

ÇINAR, Tuba, “Süveyş Kanalı'nın Açılması ve Osmanlı Dış Politikasındaki Önemi 18691882, (Gazi Üniversitesi Sosyal Bilimler Enstitüsü, Yayınlanmamış Yüksek Lisans Tezi), Ankara 2008.

ÇOLAK, Kamil, "Mısır'ın Fransızlar Tarafından İşgali ve Tahliyesi (1798-1801)", Sakarya Üniversitesi Fen Edebiyat Dergisi, C. 10, S. 2, Sakarya 2008.

DANIŞMEND, İsmail Hami, İzahlı Osmanlı Tarihi Kronolojisi, C. 4, Türkiye Yayınevi, İstanbul 1972.

DAVID, Cannon, Byron, “A Reassessment of Judicial Reform in Egypt, 1876-1891”, The International Journal of African His- torical Studies, V: 5, I: 1, Boston 1972.

DAVID, Cannon, Byron, "Nubar Pasha, Evelyn Baring and a Suppressed Article in the Drummond-Wolff Conventi- on", International Journal of Middle East Studies, V: 5, I: 4, Cambridge 1974.

DİCEY, Edward, The Egypt of The Future, William Heinemann, London 1907, s. 65; Sir Alfred Milner, England in Egypt, Edward Arnold Press, London 1902.

DUNN, John P, Khedive Ismail's Army, London-Newyork 2005.

EATHBONE, W, Great Britain and The Suez Canal, Chapman\&Hall, London 1882.

EREN, Emine, Mehmed Ali Paşa İsyanı Ve Mısır Meselesi, (Eskişehir Osmangazi Üniversitesi Sosyal Bilimler Enstitüsü, Yayınlanmamış Yüksek Lisans Tezi), Eskişehir 2008.

ERTEM, Süleyman Kani, “Saray ve Babıâli’nin İç Yüzü”, Akşam Gazetesi, Tefrika No: 395.

FAROQHI, Suraiya, Osmanlı Imparatorluğu Tarihi, Çev: Ercan Ertürk, Tarih Vakfı Yurt Yayınlar1, İstanbul 2012.

FEATHERSTONE, Donalt, Tel-El Kebir Wolseley's Conquest of Egypt, Great Britain 1993.

GENÇOĞLU, Mustafa, İngiliz Hâkimiyetinde Misır (1882-1914), (Hacettepe Üniversitesi Sosyal Bilimler Enstitüsü, Yayınlanmamış Yüksek Lisans Tezi), Ankara 1997.

GÖK, Nejdet, "Mütercim Halimi Efendi'nin Notları Çevresinde Sultan Abdülaziz'in Avrupa Seyahati ve Sonuçları(21 Haziran 1867- 7 Ağustos 1867)", Tarihin Peşinde Uluslararası Tarih ve Sosyal Araştırmalar Dergisi, S. 7, 2012. 
GÖRGÜN, Hilal, "Fransız İşgali ve Sonrası Mısır", Türkiye Diyanet Vakfi İslam Ansiklopedisi, İSAM Yayınları, C. 29, Ankara 2004.

GRANT, Jame, Cassell's History Of England From The illness Of ThePrince Of Wales To The British Occupation Of Egypt, V. VII, Cassell And Company, Limited, London 1909.

GÜLER, Zeynep, Süveyş ’in Batısında Arap Milliyetçiliği Mısır ve Nasırcılık, Yenihayat Kütüphanesi, İstanbul 1994.

GÜMÜŞ, Musa, Güç ve Diplomasi Misır Meselesi ve Sultan Abdülhamid, Kitabevi Yayınlar1, İstanbul 2018.

GÜNDAĞ, Nevzat, "Grek-Rum ve Mehmed Ali Paşa İsyanlarının Yarattığı Müsait Ortamda Doğu Akdeniz'de Devletlerarasında Denge Arayışları”, Türk Yurdu, C. 20, S. 151, Ankara 2000.

HANSEN, Bent -Khairy Tourk, "The Profitability of the Suez Canal as a Private Enterprise, 1859-1956", The Journal of Economic History, V: 38, I: 4, Cambridge 1978.

HENNEBERT, Lieut Colonel, English in Egypt England and The Suez Canal, (Translate by Permission By Bernard Pauncefote), Allen \&Co Press, London 1884.

HOURANI, Albert, Arap Halkları Tarihi, Çev: Yavuz Alogan, iletişim Yayınları, İstanbul 2009.

HUNTER, F. Robert, "Egypt Under the Successors of Muhammad" Ali" The Cambridge History of Egypt, V: 2, Modern Egypt, From 1517 to The End of the Twentieth Century, Ed: By M. W. Daly, Cambridge 1998.

İRTEM, Süleyman Kâni, Osmanlı Devleti'nin Misır Yemen Hicaz Meselesi, Haz: Osman Selim Kocahanoğlu, Temel Yayınları, İstanbul 1999.

İS-SANAFIRI, İbrahim Muhammed, Osmanlı Misır İlişsileri (1863-1882), (İstanbul Üniversitesi Sosyal Bilimler Enstitüsü, Yayınlanmamış Doktora Tezi), İstanbul 1993.

KARACA, Taha Niyazi, Büyük Oyun, Timaş Yayınları, İstanbul 2011.

KARAL, Enver Ziya, Osmanlı Tarihi, C. 7, Türk Tarih Kurumu Basımevi, Ankara 2003.

KIZILTOPRAK, Süleyman, Misır'ın Ingiltere Tarafindan İsgali Osmanlı'nın Diplomasi Savaşı (1882-1887), Tarih Vakfı Yurt Yayınları, İstanbul 2010.

KLAVEREN, Jakab Van, "Mısır'da Rüşvetin Gelişimi: Muhammed Ali Paşa'dan Hıdiv İsmail'e Kadar", Çev: Ahmet Asker, Osmanl Tarihi Araştırma ve Uygulama Merkezi Dergisi, S. 28, Ankara 2010.

KURAN, Ahmed Bedevi, Osmanlı Imparatorluğunda İnklâp Hareketleri ve Milli Mücadele, Türkiye İș Bankası Kültür Yayınları, İstanbul 2012.

KUTLUOĞLU, Muhammet Hanefi, "Mehmed Ali Paşa", Türkiye Diyanet Vakfi İslam Ansiklopedisi, İSAM Yayınları, C. 25, Ankara 2002.

KÜÇÜK, Cevdet, “Abdülaziz”, Türkiye Diyanet Vakfi İslam Ansiklopedisi, C. 1, İSAM Yayınları, İstanbul 2013. 
KÜRKÇÜOĞLU, Ömer, Türk-İngiliz İlişkileri (1919-1926), Ankara Üniversitesi Siyasal Bilgiler Fakültesi Yayınları, Ankara 1978.

MAHMUD, Seyyid Muhhamed es-Seyyid, XIV. Astrda Misır Eyaleti, Marmara Üniversitesi Yayınları, İstanbul 1990.

MARSOT, Afaf Lutfi al-Sayyid, "The Porte and Ismail Pasha's Quest for Autonomy" Journal of the American Research Center in Egypt, V: 12, 1975.

MARSOT, Al-Sayyid Afaf Lutfi, Mısır Tarihi Arapların Fethinden Bugüne, Çev: Gül Çağalı Güven, Tarih Vakfı Yurt Yayınları, İstanbul 2010.

MAYER, Ann Elizabeth, Abbas Hilmî II: The Khedive and Egypt's Struggle For Independence, V. I, Michigan: A Dissertation Submitted in Partial Fulfillment of The Requirements For The Degree Of Doctor of Philosophy, 1978.

McCOAN, J. C., Egypt, With A Supplementary Chapter Of Recent Events, Peter Fenelon Collier, New York 1893.

MiEVILLE, Sir Walter, Under Queen And Khedive The AutobiographtOf An AngloEgyptian Official, William, London1899.

MOSTOFI, Khosrow, "The Suez Dispute: A Case Study of a Treaty", The Western Political Quarterly, V: X, I: 1, 1956.

ÖZER, Sevda Özkaya, Osmanlı Devlet İdaresinde Mısır (1839-1882), (Firat Üniversitesi Sosyal Bilimler Enstitüsü, Yayınlanmamış Doktora Tezi), Elazığ 2007.

ÖZER, Sevda Özkaya, Osmanlı Devlet İdaresinde Mısır (1839-1882), (Firat Üniversitesi Sosyal Bilimler Enstitüsü, Yayınlanmamış Doktora Tezi), Elazığ 2007.

ÖZKOÇ, Özge, "İmparatorluk İktidarının Sınırında Osmanlı Mısırı: Mehmed Ali Paşa Döneminden Hidivliğe", (Ankara Üniversitesi Sosyal Bilimler Enstitüsü, Yayınlanmamış Doktora Tezi), Ankara 2013.

ÖZTÜRK, Mustafa, “Arap Ülkelerinde Osmanlı İdaresi”, History Studies Ortadoğu Özel Ssi/Middle East Special Issue, Samsun 2010.

Tahsin Paşa, Yıldız Hatıraları Sultan II. Abdülhamid, Boğaziçi Yayınları, İstanbul 1999.

PINAR, Hayrettin, Babıâli ve Hıdiv İsmail, Kitap Yayınevi, İstanbul 2012.

PULLERTON, William Morton, The Memoirs Of İsmail Kemal Bey, Constable And Company Ltd, London 1920.

RAGATZ, Lowell Joseph, The Question of Egypt in Anglo-French Re-lations 1875-1904, Fletcher Pembroke, Edinburgh-Bombay-Sydney 1922.

RAIF, Rağıp -Rauf Ahmed, Misır Meselesi, Matbaa-i Amire, İstanbul 1334.

REID, Donald Malcolm, "Cultural Imperialism and Nationalism: The Struggle to Define and Control the Heritage of Arab Art in Egypt", International Journal of Middle East Studies, V: 24, I: 1, Cambridge 1992.

SABRY, M, "Nubar Paşa", MEB İslam Ansiklopedisi, C. IX, Millî Eğitim Basımevi, İstanbul 1964.

SAMUR, Sebahattin, "Mehmed Ali Paşa'nın (1770-1849) Sosyal Politikaları; Mısır ve Diğer Osmanlı Eyaletlerindeki Etkisi”, Bilimname, S. 13, 2007. 
SHIH, Wang Tsung, "Lord Salisbury and The Justification Of The British Position in Egypt”, Euramerica, V. 26, I. 4, 1996.

SOYSAL, İsmail, Fransiz Ihtilali ve Türk-Fransız Diplomasi Münasebetleri(1789-1802), TTK Yayınları, Ankara 1987.

ŞAHİN, Hasan, "Doğu Sorunu Çerçevesinde Osmanl1-Fransız İlişkileri (Başlangıcından Paris Barışı'na 1856)", Atatürk Üniversitesi Türkiyat Araştırmaları Enstitüsü Dergisi, S. 40, Erzurum 2009.

ŞAM, Emine Altunay, Misır'ın 1882'de Ingilizler Tarafindan İşgali ve Osmanl Devletinin Takip Ettiği Siyaset, (Ondokuz Mayıs Üniversitesi Sosyal Bilimler Enstitüsü, Yayınlanmamış Doktora Tezi), Samsun 2001.

TRAILL, H. D, Lord Cromer, Bliss, Sands and Co, London 1897.

TUGAY, Emine Fuat, Bir Aile Üç Asır, Çev: Şeniz Türkömer, Türkiye İş Bankası Kültür Yayınlar1, İstanbul 2015.

TURAN, Namık Sinan, Imparatorluk ve Diplomasi, İstanbul Bilgi Üniversitesi Yayınları, İstanbul 2015.

WALlACE, D. Mackenzie, Egypt and The Egyptian Question, Macmillan And Co, London 1883.

WILSON, Sir Arnold T, Suez Canal its Pasty Present, and Future, Second Edition, Oxford University Press, London 1939.

WORSFOLD, W. Basil, The Future Of Egypt, Collins Clear Type Press, London.

YUSUF ZIYA, Misır ve Ordusu, Matbaa-i Askeriye, İstanbul 1330. 